\title{
PHASE RELATIONS IN THE SYSTEM Au-Cu-Ag AT LOW TEMPERATURES, BASED ON NATURAL ASSEMBLAGES
}

\author{
JOHN KNIGHT ${ }^{\S}$ \\ RR\#1, Site 29, Comp. 10, Smithers, British Columbia VOJ 2NO, Canada \\ CRAIG H.B. LEITCH \\ 492 Isabella Point Road, Salt Spring Island, British Columbia V8K 1V4, Canada
}

\begin{abstract}
The composition of some 85 particles of native gold from the 15 Mile rodingite in serpentinite showing in the Coquihalla gold district and the Wheaton Creek placer in the Dease Lake district, British Columbia, falls mainly within the $\mathrm{Cu}$-rich portion of the $\mathrm{Au}-\mathrm{Ag}-\mathrm{Cu}$ phase diagram. The particles display a variety of textures, including exsolution-induced textures. The textures and phase compositions are used to construct a low-temperature phase diagram for the system $\mathrm{Au}-\mathrm{Ag}-\mathrm{Cu}$. This diagram represents a system that equilibrated for a longer period of time at a lower temperature than is accessible in synthetic systems. In this diagram, the composition $\mathrm{AuCu}$ is nearly stoichiometric, a three-phase region is found among $\mathrm{AuCu}\left(\mathrm{Au}_{1.0} \mathrm{Cu}_{0.971} \mathrm{Ag}_{0.003}\right), \mathrm{Au}_{2} \mathrm{Cu}$ $\left(\mathrm{Au}_{2.0} \mathrm{Cu}_{0.962} \mathrm{Ag}_{0.045}\right)$, and $\mathrm{Au}_{3.0} \mathrm{Ag}_{0.71} \mathrm{Cu}_{0.23}$, and there is a two-phase region on the $\mathrm{Au}$ side of the $\mathrm{Au}_{2} \mathrm{Cu}-\mathrm{Au}_{3.0} \mathrm{Ag}_{0.71} \mathrm{Cu}_{0.23}$ join. There are insufficient data to determine the phase relationships that exist between the compositions $\mathrm{Au}$ and $\mathrm{Au}_{2} \mathrm{Cu}$, which includes $\mathrm{Au}_{3} \mathrm{Cu}$. $\mathrm{Au}_{2} \mathrm{Cu}$ may or may not be part of a solid solution centered around $\mathrm{Au}_{3} \mathrm{Cu}$. The sequence of formation of extensive exsolution-induced textures and their relation to the other textures seen are explained by combining the phase diagram with a significant shift in the position of the solvi with temperature in this system. Low values of $\mathrm{Ag}$ in $\mathrm{Au}-\mathrm{Cu}$ alloy and of $\mathrm{Cu}$ in $\mathrm{Au}-$ $\mathrm{Ag}$ alloy are reported. Grains of gold alloy from deposits where no $\mathrm{Au}-\mathrm{Cu}$ alloy is found appear to be undersaturated with respect to $\mathrm{Cu}$.
\end{abstract}

Keywords: native gold, $\mathrm{Au}-\mathrm{Ag}-\mathrm{Cu}$ alloys, phase diagram, exsolution, composition, 15 Mile showing, Wheaton Creek placer, British Columbia.

\section{SOMMAIRE}

La composition d'environ 85 particules d'or natif provenant de l'indice 15 Mile, dans une rodingite associée à une serpentinite du district aurifère de Coquihalla, et du placer de Wheaton Creek, du district de Dease Lake, en Colombie-Britannique, se situe surtout dans la partie riche en cuivre du système $\mathrm{Au}-\mathrm{Ag}-\mathrm{Cu}$. Ces particules font preuve d'une variété de textures, dont des textures indicatives d'une exsolution. Les textures et la composition des phases servent à construire un diagramme de phases pour le système $\mathrm{Au}-\mathrm{Ag}-\mathrm{Cu}$ approprié à de faibles températures. Ce diagramme représente un système qui a progressé vers un état d'équilibre durant une période de temps beaucoup plus longue que ne serait possible en système synthétique. Dans ce diagramme, la composition $\mathrm{AuCu}$ est presque stoéchiométrique, une région à trois phases a été découverte impliquant $\mathrm{AuCu}$ $\left(\mathrm{Au}_{1.0} \mathrm{Cu}_{0.971} \mathrm{Ag}_{0.003}\right), \mathrm{Au}_{2} \mathrm{Cu}\left(\mathrm{Au}_{2.0} \mathrm{Cu}_{0.962} \mathrm{Ag}_{0.045}\right)$, et $\mathrm{Au}_{3.0} \mathrm{Ag}_{0.71} \mathrm{Cu}_{0.23}$, et il y a une région à deux phases dans la région vers le pôle $\mathrm{Au}$ par rapport à l'assemblage $\mathrm{Au}_{2} \mathrm{Cu}-\mathrm{Au}_{3.0} \mathrm{Ag}_{0.71} \mathrm{Cu}_{0.23}$. Les données disponibles ne suffisent pas pour déterminer les relations de phases entre les compositions $\mathrm{Au}$ et $\mathrm{Au}_{2} \mathrm{Cu}$, domaine qui inclut $\mathrm{Au}_{3} \mathrm{Cu}$. Le composé $\mathrm{Au}_{2} \mathrm{Cu}$ pourrait ou non faire partie d'une solution solide centrée autour de $\mathrm{Au}_{3} \mathrm{Cu}$. La séquence de formation généralisée de textures attribuables à l'exsolution et leurs relations aux autres textures observées peuvent s'expliquer avec ce diagramme de phase, compte tenu du déplacement important du solvus avec la température dans ce système. Nous décrivons de faibles niveaux de $\mathrm{Ag}$ dans l'alliage $\mathrm{Au}-\mathrm{Cu}$ et de $\mathrm{Cu}$ dans l'alliage $\mathrm{Au}-\mathrm{Ag}$. Les grains d'alliage à dominance d'or provenant des gisements dépourvus d'alliage $\mathrm{Au}-\mathrm{Cu}$ semblent être sous-saturés par rapport au $\mathrm{Cu}$.

(Traduit par la Rédaction)

Mots-clés: or natif, alliages $\mathrm{Au}-\mathrm{Ag}-\mathrm{Cu}$, diagramme de phases, exsolution, composition, indice 15 Mile, placer de Wheaton Creek, Colombie-Britannique.

§ E-mail address: microsci@mail.bulkley.net 


\section{INTRODUCTION}

Geologists have long recognized that naturally occurring gold is usually an alloy, with Ag being the principal alloying element (Boyle 1979). Naturally occurring $\mathrm{Au}-\mathrm{Ag}$ alloy commonly contains varying trace amounts of copper, mercury and, more rarely, other elements (e.g., Boyle 1979, Knight \& McTaggart 1989). Such Au-Ag alloy is found in all gold deposits containing native gold. In rare instances, the trace elements (e.g., $\mathrm{Hg}, \mathrm{Cu}, \mathrm{Pd}, \mathrm{Bi})$ may occur in sufficient concentration to form an alloy with gold and silver. These compositions of alloy are generally restricted in their occurrence. For example, alloy in the $\mathrm{Cu}-\mathrm{Au}$ series with $>5 \mathrm{wt} \% \mathrm{Cu}$ are usually only reported from lode deposits associated either with layered mafic intrusions (e.g., Bird et al. 1991) or with altered ultramafic rocks (e.g., Murzin et al. 1987, Knipe \& Fleet 1997) and their associated placers. Knowledge of the phase relations within these alloy compositions can help in the understanding of the formation of their lode hosts. The details of the $\mathrm{Au}-\mathrm{Cu}-\mathrm{Ag}$ and $\mathrm{Au}-\mathrm{Cu}$ phase diagrams at the lower temperatures of geological interest are not well known because of both the low kinetic rates of separation of the phases in synthetic systems (Okamoto et al. 1987) and the rare occurrence of these alloy compositions in nature. It is our aim in this study to use the compositions of naturally occurring $\mathrm{Au}-\mathrm{Cu}-\mathrm{Ag}$ alloy from Wheaton Creek and the 15 Mile showing, in British Columbia, to determine the details of the $\mathrm{Au}-\mathrm{Cu}-\mathrm{Ag}$ phase diagram at low temperatures. The gold at these locations has been equilibrating at near-surface temperature for thousands (if not millions) of years, a condition unavailable in synthetic systems. The data provide a framework for a discussion of the formation of these rare alloy compositions.

\section{Previous Work Within the System Au-Cu-Ag}

The binary system $\mathrm{Au}-\mathrm{Ag}$ forms a continuous solidsolution above about $25^{\circ} \mathrm{C}$ (Dowdell et al. 1943, White et al. 1957), although Petrovskaya et al. (1977) and Petrovskaya \& Novgorodova (1980) suggested that Agrich alloy may unmix into $\mathrm{AuAg}$ and $\mathrm{AuAg}_{3}$ at low temperatures. The system $\mathrm{Au}-\mathrm{Cu}$ has been studied both experimentally and theoretically. The experimental studies have been conducted both with and without Ag (Barrett \& Massalski 1980, Kogachi \& Nakahigashi 1980, Okamoto et al. 1987). The properties of synthetic alloy compositions in the Ag-absent system $\mathrm{Au}-\mathrm{Cu}$ have been reviewed by Knipe \& Fleet (1997, Table 1), whereas Okamoto et al. (1987) provided a comprehensive review of the experimental results in this system. In the synthetic $\mathrm{Ag}$-absent binary system $\mathrm{Au}-\mathrm{Cu}$, a continuous series is found only at temperatures above about $400^{\circ} \mathrm{C}$ (at 1 atmosphere) (Barrett \& Massalski 1980, Okamoto et al. 1987). Below $400^{\circ} \mathrm{C}$, the phases order into a superlattice structure with miscibility gaps be- tween them. The resulting $\mathrm{Au}-\mathrm{Cu}$ phase diagram contains seven phases: $\mathrm{Au}, \mathrm{Cu}$, two polymorphs of $\mathrm{AuCu}$ (tetra-auricupride), $\mathrm{Au}_{3} \mathrm{Cu}$ (auricupride), and two polymorphs of $\mathrm{AuCu}_{3}$. The phases $\mathrm{AuCu}$ and $\mathrm{AuCu}_{3}$ are well characterized both in synthetic and natural systems (Okamoto et al. 1987, Knipe \& Fleet 1997), although in synthetic systems their reported compositional range is very large compared to the natural examples. The phase $\mathrm{Au}_{3} \mathrm{Cu}$ is not well characterized [ $c f$. the findings of Barrett \& Massalski (1980) with those of Okamoto et al. (1987) and Knipe \& Fleet (1997)]. In the Ag-present system $\mathrm{Au}-\mathrm{Cu}$, Kogachi \& Nakahigashi (1980) used synthetic alloy compositions to create a phase diagram, whereas Kikuchi et al. (1980) produced a calculated coherent phase-diagram for the system between $530^{\circ}$ and $240^{\circ} \mathrm{C}$ (Fig. 1). There is a general correspondence between the theoretically expected and synthetic phases, but they differ in detail (Yamauchi et al. 1981). The correspondence between the experimental and natural systems is better, but the details predicted in the theoretical study are lacking in the studies of naturally occurring alloy compositions. The theoretical work defined both two- and three-phase regions and documented the general shift of the phase boundaries with temperature. Results of both the theoretical and synthetic studies show a rapid shift of the solvi toward the $\mathrm{Au}$ apex as temperature decreases below about $400^{\circ} \mathrm{C}$. Below about $200^{\circ} \mathrm{C}$, details in the synthetic systems are poorly known; the boundary between the one-phase and two-phase fields near the Au apex is usually drawn as in Figure 2 (curved line nearest $\mathrm{Au}$ ). The possible multiphase portion around $\mathrm{Au}_{3} \mathrm{Cu}$ is usually omitted. These results imply that at low temperatures, Au alloy compositions with both significant $\mathrm{Cu}$ and $\mathrm{Ag}$ will only be found near the Au apex.

Naturally occurring alloy compositions in the system $\mathrm{Au}-\mathrm{Cu}$ are rare. Knipe \& Fleet (1997) provided a review of many of the reports dealing with natural $\mathrm{Au}-$ $\mathrm{Cu}$ alloy. The following continues their review. The Urals region is recognized by Russian geologists as a gold-rich metallogenic province in which samples of $\mathrm{Au}-\mathrm{Ag}$ alloy contain above-average levels of $\mathrm{Cu}$ and $\mathrm{Hg}$, and $\mathrm{Au}-\mathrm{Cu}$ alloy is common (e.g., Murzin \& Malyugin 1983, Murzin \& Moloshag 1986). Au-Cu alloy $(\mathrm{Cu}$ to $2.5 \mathrm{wt} \%)$ is associated with chalcopyritesphalerite ores in basaltic volcanic rocks (Murzin \& Moloshag 1986) and deposits hosted by altered serpentinites (Murzin et al. 1987). Novgorodova \& Tsepin (1976) described four types of $\mathrm{Cu}-\mathrm{Au}-\mathrm{Ag}$ alloy from the Karabash deposit, Urals. The alloy particles are composites, consisting of a core of $\mathrm{AuCu}$ (Ag to 0.55 wt\%) with a rim of $\mathrm{AuCu}_{3}$. $\mathrm{An} \mathrm{Au}-\mathrm{Ag}$ alloy (Ag to 49.3 wt $\%$ ) with variable levels of mercury (to $10 \mathrm{wt} \%$ ) also occurs in the core of the particles. A low-Ag alloy with up to $7.5 \mathrm{wt} \% \mathrm{Cu}$ is found along the contact between $\mathrm{AuCu}$ and $\mathrm{AuCu}_{3}$. Pokrovskii \& Berzon (1975) and Pokrovskii et al. (1979) reported on the wide variety of alloys in the system $\mathrm{Au}-\mathrm{Cu}-\mathrm{Ag}$ system from the 


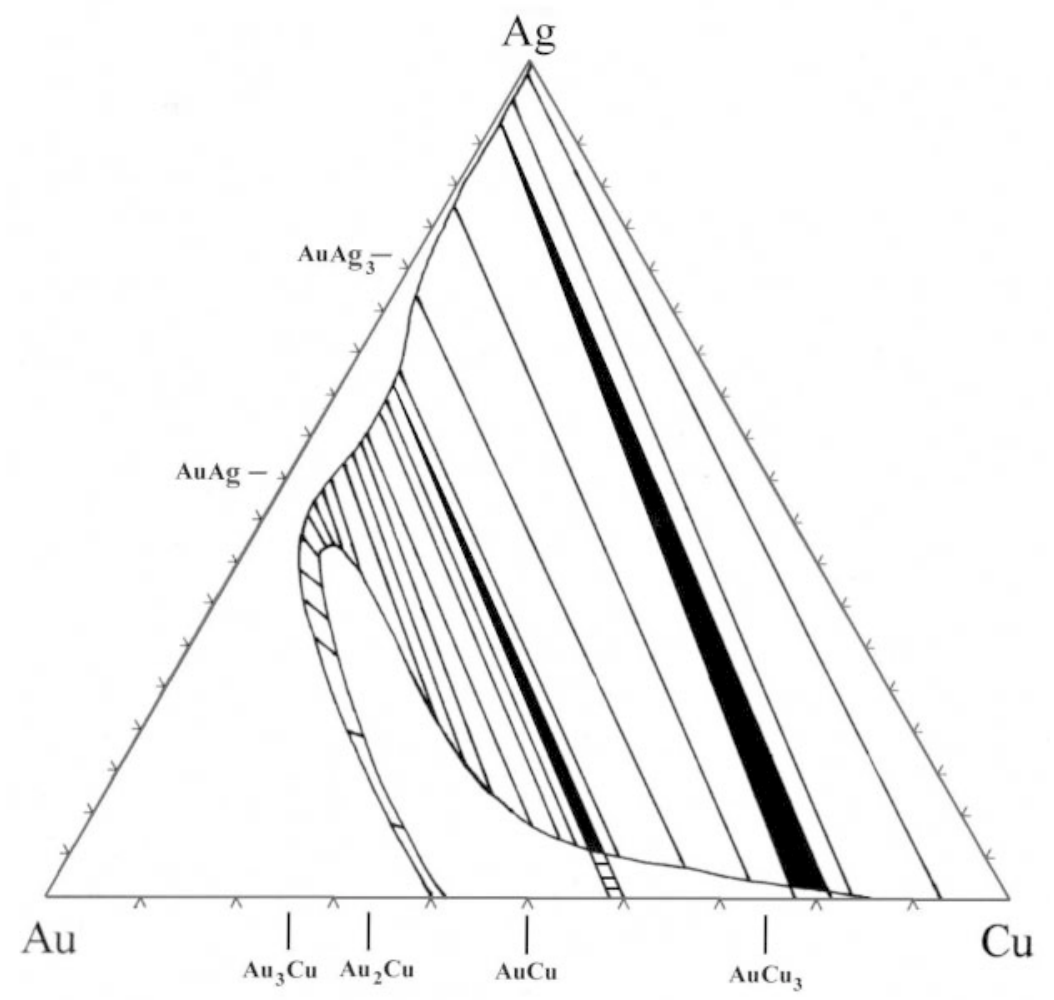

FIG. 1. The calculated phase-diagram for the system $\mathrm{Au}-\mathrm{Cu}-\mathrm{Ag}$ at $240^{\circ} \mathrm{C}$, expressed in atomic \%, from Kikuchi et al. (1980). Black areas denote three-phase assemblages. Tielines join phases in two-phase areas.

Zolotaya Gora deposit, southern Urals. The particles of alloy are composites that typically consist of a Cu-poor core and a Cu-rich rim. Figure 1 in Pokrovskii et al. (1979) shows the following phases: 1) native copper, 2) native silver, 3) $\mathrm{Au}-\mathrm{Cu}$ alloy with $40-50 \mathrm{wt} \% \mathrm{Cu}$, with up to $\left.1.5 \mathrm{wt} \% \mathrm{Ag}\left(\mathrm{AuCu}_{3}\right), 4\right) 20-30 \mathrm{wt} \% \mathrm{Cu}$ with up to $2 \mathrm{wt} \% \mathrm{Ag}(\mathrm{AuCu}), 5) 0-10 \mathrm{wt} \% \mathrm{Cu}, 2-10 \% \mathrm{Ag}, 6)$ $\mathrm{Au}-\mathrm{Ag}$ alloy with $20 \mathrm{wt} \% \mathrm{Ag}, 0-2 \mathrm{wt} \% \mathrm{Cu}, 7) 33-37$ wt $\% \mathrm{Ag}, 0 \mathrm{wt} \% \mathrm{Cu}$, and 8) 45-55 wt $\% \mathrm{Ag}, 0 \mathrm{wt} \% \mathrm{Cu}$, $5-10 \mathrm{wt} \% \mathrm{Hg}$ (the level of $\mathrm{Hg}$ increases with $\mathrm{Ag}$ content). By studying etched samples recovered from a "chlorite - garnet - pyroxene" rock (rodingite?) of the southern Urals (Altai-Saiany) and the western slopes of the Urals with an electron microscope, Murzin \& Sustavov (1989) were able to describe details of the general exsolution-induced textures in the system $\mathrm{Au}-\mathrm{Cu}-$ $\mathrm{Ag}$. These textures usually consist of laths of varying thickness, length and taper arranged in subparallel to net-like configurations within the host. They also described the cell parameters of nearly stoichiometric $\mathrm{AuCu}$ (both orthorhombic and tetragonal) and $\mathrm{AuCu}_{3}$. They reported the occurrence of both orthorhombic and tetragonal $\mathrm{AuCu}$ in a single particle of gold. They noted that long-range ordering only occurs in compositions near stoichiometry. For compositions deviating from stoichiometry, incomplete exsolution results in phases with slight excesses of $\mathrm{Au}, \mathrm{Cu}$ or $\mathrm{Ag}$ with respect to the ideal. They described and illustrated exsolution textures within nearly stoichiometric $\mathrm{AuCu}$ and $\mathrm{Au}_{3} \mathrm{Cu}$. For a sample with excess $\mathrm{Cu}$ over stoichiometric $\mathrm{Au}_{3} \mathrm{Cu}$, they reported the exsolution of a low-fineness $\mathrm{Ag}-\mathrm{Au}$ alloy and an $\mathrm{Au}-\mathrm{Cu}$ alloy. The $\mathrm{Au}-\mathrm{Cu}$ alloy has the composition $86 \mathrm{wt} \% \mathrm{Au}, 12.0-12.5 \% \mathrm{Cu},<2.0 \% \mathrm{Ag}, 0 \% \mathrm{Hg}$. For a sample with excess $\mathrm{Au}$ with respect to $\mathrm{Au}_{3} \mathrm{Cu}$, they reported on the basis of diffraction data that the exsolved $\mathrm{Cu}$-rich phase matches the lines expected of synthetic $\mathrm{Au}_{3} \mathrm{Cu}$. Kuznetsov et al. (1977) reported on multiphase $\mathrm{Au}-\mathrm{Cu}$ alloy compositions ranging from 1 to $31 \mathrm{wt}($ ?) $\% \mathrm{Cu}, 1-15 \% \mathrm{Ag}$ from heavy-mineral samples within the Donetsk drainage basin, Russia.

Bird et al. (1991) reported the presence of $\mathrm{Cu}-\mathrm{Au}$ and $\mathrm{Au}-\mathrm{Ag}$ alloys from the Skaergaard layered mafic intrusion, in eastern Greenland. Up to 8 at.\% Pd is present in some of the alloys. In terms of the ternary system $\mathrm{Au}-\mathrm{Cu}-\mathrm{Ag}$, these compositions plot near 47 at. $\% \mathrm{Au},<2 \% \mathrm{Ag}, 51 \% \mathrm{Cu}$, joining compositions near $70-75$ at. $\%, 5 \% \mathrm{Cu}, 25-30 \%$ Ag. From northwestern China, Mao \& Liu (1984) reported phases with compo- 


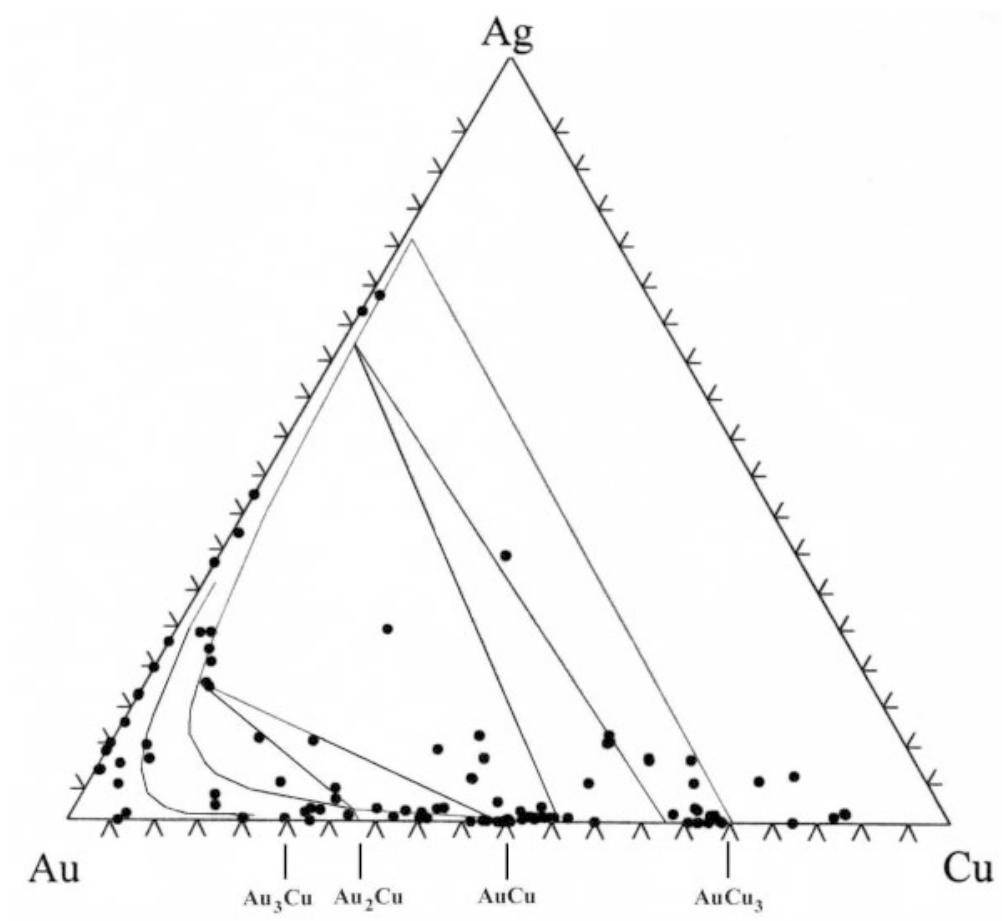

FIG. 2. Data from previous studies of naturally occurring examples of high-Cu gold alloy. The data (in at.\%) are taken from the references mentioned in the Previous Work section. For convenience, the phase boundaries presented in Figure 8 also are displayed.

sitions $\mathrm{Au}_{3} \mathrm{Cu}_{2}$ and $\mathrm{Au}_{2} \mathrm{Cu}$, but were not confident of their results. Bowles (1984) reported $\mathrm{Au}-\mathrm{Cu}$ alloy compositions in alluvial samples from Sumatra, with compositions 14.5 at. $\% \mathrm{Au}, 79.4 \% \mathrm{Cu}, 6.1 \% \mathrm{Ag}$ and 52.0 at. $\% \mathrm{Au}, 47.9 \% \mathrm{Cu}$ and $0.1 \% \mathrm{Ag}$ in association with $\mathrm{Au}-\mathrm{Ag}$ alloys of composition 83-100 at.\% Au, 17-0\% Ag. Stumpfl \& Clark $(1965,1966)$ reported an occurrence in southern Borneo (Kalimantan) of $\mathrm{Au}-\mathrm{Cu}$ alloy compositions (up to $30 \mathrm{wt} \% \mathrm{Cu}$ ) from alluvial concentrates, associated with platinum-group minerals (PGM). In British Columbia, Raicevic \& Cabri (1976) reported an occurrence in alluvial samples of $\mathrm{Au}-\mathrm{Cu}$ alloy (0-30 wt $\% \mathrm{Cu}, 10-30 \% \mathrm{Ag}$ ) associated with PGM.

Results from these earlier studies are presented in Figure 2 which, for convenience, also displays the phase diagram deduced from this study. The data from the previous studies are presented as reported, with no attempt to separate out compositions referring to multiphase assemblages, or poor-quality analyses. The literature review shows that the phase $\mathrm{AuCu}$ is reported most frequently. The phases $\mathrm{AuCu}_{3}$ and $\mathrm{Au}_{3} \mathrm{Cu}$ are reported less frequently than $\mathrm{AuCu}$. From Figure 2, clusters of compositions around $\mathrm{AuCu}$ and $\mathrm{AuCu}_{3}$ are within about 5 at.\% of the ideal formula. Compositions do not cluster around $\mathrm{Au}_{3} \mathrm{Cu}$. It is unclear whether at low tem- peratures this phase is $\mathrm{Au}_{3} \mathrm{Cu}$, part of a solid solution that includes the compositions from $\mathrm{Au}_{2} \mathrm{Cu}$ to near $\mathrm{Au}$, or whether the phase $\mathrm{Au}_{3} \mathrm{Cu}$ decomposes into a $\mathrm{Cu}$-rich $\left(\mathrm{Au}_{2} \mathrm{Cu}\right.$ ?) and an Au-rich phase. All of these natural phases contain varying amounts of $\mathrm{Ag}$. Some of the other $\mathrm{Au}-\mathrm{Cu}$ and $\mathrm{Au}-\mathrm{Cu}-\mathrm{Ag}$ alloys that have been reported probably represent mixtures. For example, Mao \& Liu (1984) reported on $\mathrm{Au}_{3} \mathrm{Cu}_{2}$ as a phase, but on the basis of this study and a review of their work, that phase probably represents a mixture of exsolved phases. The description and interpretation of natural $\mathrm{Au}-\mathrm{Cu}$ phases based on electron-microprobe-derived compositions are complicated by the possibility that exsolved phases may be present but unrecognized because of their very small size $(<1 \mu \mathrm{m})$.

\section{Geological Context of Analyzed Samples}

A literature review reveals that in nearly all cases, $\mathrm{Au}-\mathrm{Cu}$ alloys are found in ores associated with differentiated mafic magmas, or in serpentinite, rodingite and other altered ultramafic rocks, usually associated with ophiolite complexes. The occurrences of gold sampled for this study are no exception. The 15 Mile lode showing is located in southwestern British Columbia near the 
head of 15 Mile Creek, which drains into the Coquihalla River (NTS 92H6 and 92H11) (Ray 1990, Fig. 23, showing \#8). The showing lies within a $2-\mathrm{km}$ wide belt of serpentinite, fault-bounded on a regional scale, NWSE-trending and steeply dipping (Ray 1990). The gold is hosted by rodingites and talc-filled shear zones within the serpentinite body. Cairnes (1930) reported that the thinnest veins of rodingite seem to carry the highest $\mathrm{Au}$ grades. He reported that some of the gold is present as smears on talc-lined shear faces, suggesting at least some fault movement after ore formation. There are a number of lode deposits within $4 \mathrm{~km}$ of the 15 Mile showing and within $1 \mathrm{~km}$ of the fault. They fall into four classes (sulfide-poor quartz or quartz-carbonate veins, sulfide-rich quartz stockworks, talc-lined shear zones, and talc-lined shear zones in rodingite). Although many of the showings have resulted in small mines, the only mine of significance was the Carolin quartz stockwork deposit. Ray (1990) concluded that all the deposits in the area were formed by a "common" mineralizing event that was strongly controlled by the faults bounding the serpentinite body. The fineness [1000* Au wt $\% /(\mathrm{Ag}$ $\mathrm{wt} \%+\mathrm{Au} \mathrm{wt} \%)]$ of the gold from all other types of deposit (other than the 15 Mile occurrence) varies from 863 to 907 (Knight \& McTaggart 1989, 1990), with a pronounced maximum near a fineness of 870 (78.6 at.\% $\mathrm{Au}$ and $21.4 \% \mathrm{Ag}$ ). The variation in fineness for a specific lode is small. $\mathrm{Cu}$ is present from below detection limit to $0.047 \mathrm{wt} \%$ (to 0.12 at.\%). Mercury is present in this gold at levels of up to $0.3 \mathrm{wt} \%$, with most values falling between 0.1 and $0.2 \%$. The 15 Mile sample was collected by panning the dump surface and the floor of what was deduced to be the crusher-concentrator. Both are located immediately below the collapsed portal. By comparing the material on the tip and crusher floor, it seems likely that rodingite material was preferentially selected for crushing. The gold sample is considered to represent most of the types of gold mined. Under the microscope, some of the gold in the concentrate could be seen to be intergrown with a pyroxene (diopside?). Magnetite and a garnet also were recognized. Particles in the 0.1 to $0.25 \mathrm{~mm}$ range were selected from the concentrate for analysis.

The Wheaton Creek placer is located in north-central British Columbia, at the mouth of Wheaton Creek, where it drains into the Turnagain River (NTS $104 \mathrm{I} 6$ and 104I7) (Holland 1940, Fig. 1, Roosevelt Lease). The lode source for the placer gold is unknown, although Holland (1940) concluded that the source was in the immediate vicinity. This is supported by the observation that the gold particles are very weakly deformed, with a low flatness and roundness, with almost no development of a secondary rim (Knight et al. 1999). No other lode deposits have been reported from the immediate area. For most of its length, Wheaton Creek drains a 3- to 6-km wide, NW-SE-trending body of serpentinite (Holland 1940). The Wheaton and 15 Mile serpentinite bodies and their bounding faults are part of a terrane suture joining the Stikinia and Cache Creek terranes (Monger et al. 1982). The area was glaciated, and glacial drift covers much of the area. A sample of concentrate, collected in the 1980s from the placer mine, was provided by a miner. Under the microscope, the concentrate is seen to be dominated by magnetite, but numerous particles of native copper, rounded pyrite, minor arsenopyrite, chromian spinel and platinumgroup minerals, as well as gold, were also recovered. The native copper is intergrown with bornite in some cases. Holland (1940) reported the presence of much magnetite and a $\mathrm{Ni}-\mathrm{Fe}$ alloy (awaruite) in the concentrate from mining. He also recovered magnetite, pyrite, pyrrhotite, and chromian spinel from crushed samples of serpentinite. For this study, gold particles in the size range 0.5 to $0.8 \mathrm{~mm}$ were selected for analysis.

\section{Analytical Methods}

In this study, 33 particles of gold alloy from the 15 Mile lode showing and 42 particles of gold alloy from the Wheaton Creek placer were studied by electronmicroprobe analysis. The particles were prepared for analysis using the method described in Douma \& Knight (1994). A polishing technique that generated the best polish with the minimum cross-contamination was developed by repeated polishing, microscopic observation and analysis of test samples. The polished section for each particle was photographed (examples in Fig. 3) and described under reflected light. The sections were analyzed using a Cameca SX-50 electron microprobe. The analyses were conducted at $20 \mathrm{kV}$ with $100 \mathrm{nA}$ beam current to measure the level of concentration of $\mathrm{Cu}, \mathrm{Au}$, $\mathrm{Hg}$, and $\mathrm{Ag}$ using $\mathrm{Au} M \alpha, \operatorname{Ag} L \alpha, \mathrm{Cu} K \alpha$, and $\operatorname{Hg} M \beta$. Pure-element standards were used for $\mathrm{Au}$ and $\mathrm{Ag}$; an $\mathrm{Au}-\mathrm{Cu}$ alloy with $40 \mathrm{wt} \% \mathrm{Cu}$ and synthetic $\mathrm{HgTe}$ were used for $\mathrm{Cu}$ and $\mathrm{Hg}$, respectively. The NBS $\mathrm{Au}-\mathrm{Ag}$ and $\mathrm{Au}-\mathrm{Cu}$ series of alloy compositions were used as standards. In order to reproduce the compositions of the NBS $\mathrm{Au}-\mathrm{Cu}$ series of standards, the $\mathrm{Au}-\mathrm{Cu}$ absorption factor had to be changed. Many of the points selected for analysis using reflected light were checked in the microprobe using back-scattered electron (BSE) imaging. Adjusting the BSE detector for optimal imaging is difficult for small differences at high atomic numbers. As a result, it is probable that not all inhomogeneities were recognized, especially in the Au-rich phases. $\mathrm{Hg}$ is present to less than $2 \mathrm{wt} \%$, with all but a few points showing less than $0.5 \mathrm{wt} \%$. The element sums suggest that if other elements are present, values are less than $0.5 \mathrm{wt} \%$. No other elements were recognized in random energy-dispersion X-ray analyses.

Naturally occurring particles of $\mathrm{Au}-\mathrm{Cu}$ alloy are commonly multiphase (Fig. 4), being composed of either exsolution-induced intergrowths of different $\mathrm{Au}-$ $\mathrm{Cu}$ alloys (at all scales), or intergrowths of independent phases, or both (Murzin \& Sustavov 1989; this study, Fig. 3). Many of the phases approach the minimum size- 

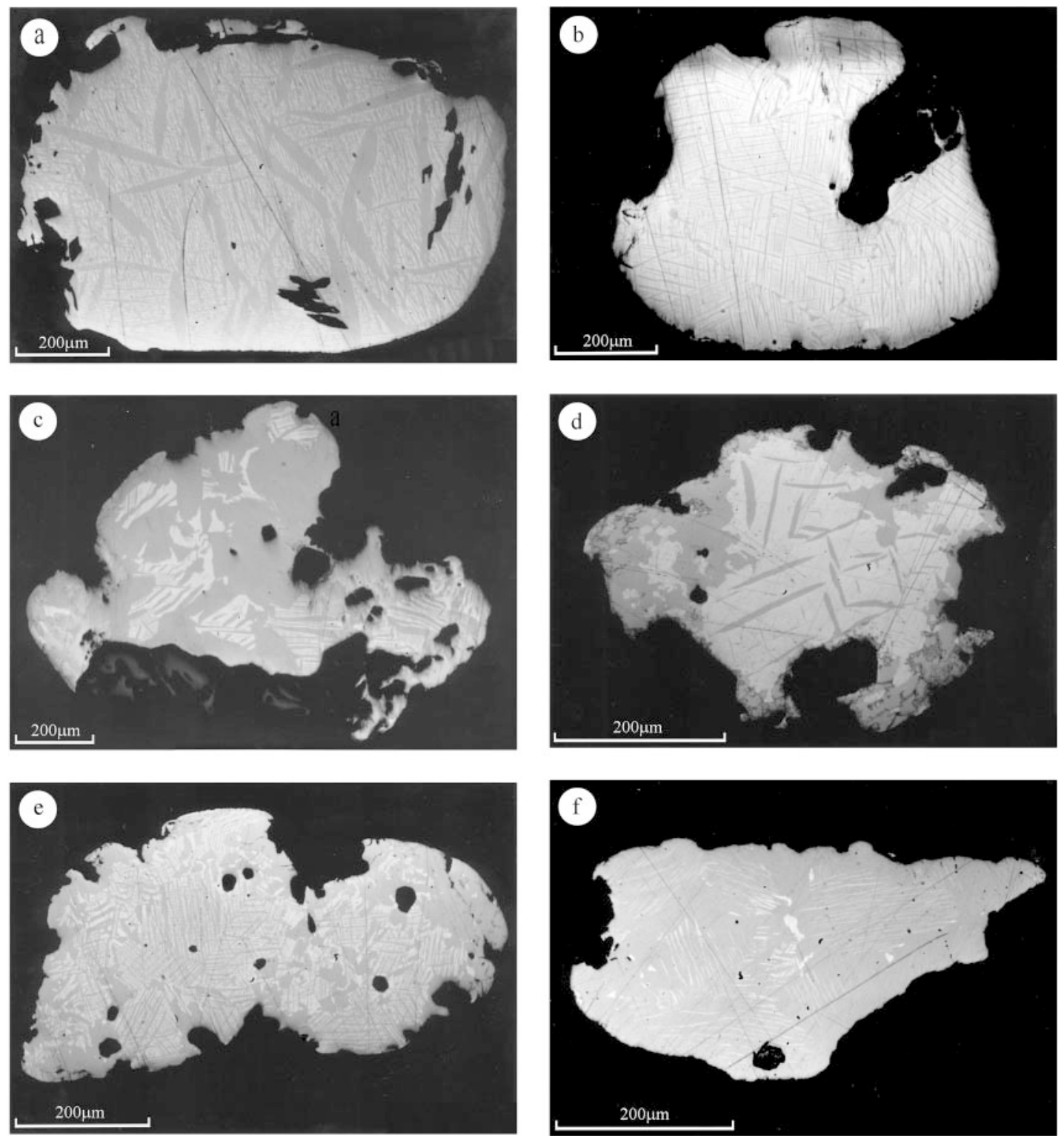

FIG. 3. Reflected-light photographs (uncrossed polars) of polished particles of placer gold from Wheaton Creek. Figures 3a-f illustrate the variation in form and degree of exsolution as well as the range in size and shape of the grains of gold alloy making up the placer particles. Grains are identified by exsolution domains and blebby areas. The blebby texture is illustrated in Figure 3c (dark upper left), and e (dark and light at neck), and the massive texture is shown in Figure 3c (right central margin) and d (lower right margin). Figure 3d illustrates a distinct edge-zone. Light areas are Au-rich, whereas dark areas are $\mathrm{Cu}$-rich. Scale bar is $200 \mu \mathrm{m}$ for all images.

limit of a few micrometers imposed by electron-microprobe analysis using $\mathrm{X}$ rays. Gold alloys are soft, which can result in cross-contamination of the phases during polishing. These two factors impose limits on the inter- pretation of the analytical data, so that the following tests were conducted to quantify these limits. An idea of the levels of sample-wide contamination through polishing was obtained by measuring the $\mathrm{Cu}$ content in 

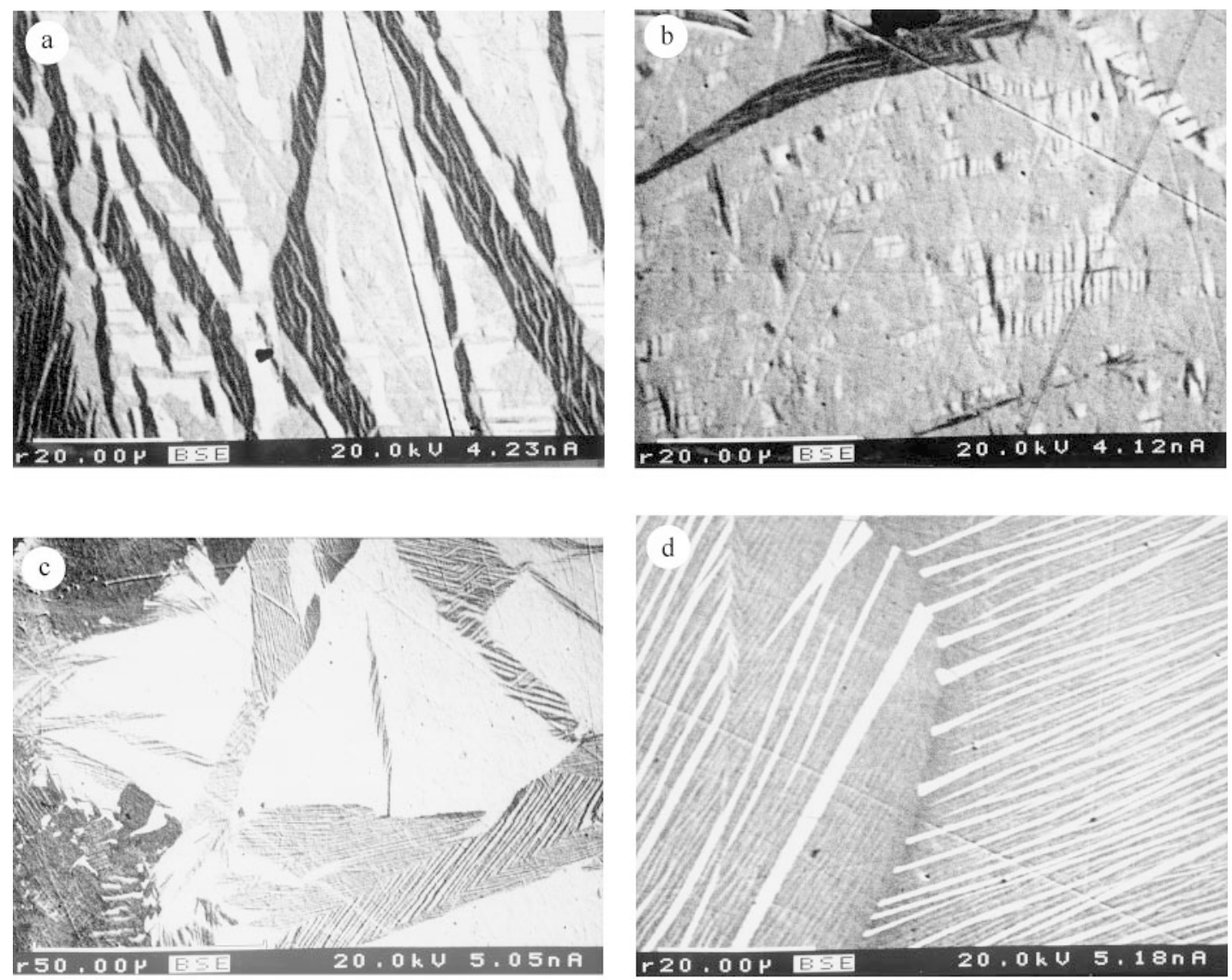

FIG. 4. Details of the exsolution-induced domains as seen in back-scattered electron images. Figures $4 \mathrm{a}$, $\mathrm{b}$ and d show material from Wheaton Creek, and Figure 4c shows material from the 15 Mile showing. Figure 4a illustrates details between the dark laths in Figure 3a. The black area at the bottom left of Figure 4a is one of the laths in Figure 3a. The forms seen in Figures 4a and $b$ are interpreted to be the result of exsolution into a developing three-phase region. Figure $4 \mathrm{c}$ illustrates blebby phases (bottom left) on the edge of an exsolved area. The presence of extremely small intimately intergrown exsolved domains illustrates one of the difficulties of chemical analysis. These images also illustrate the need for a high-quality polish in order to avoid obscuring details or cross-contaminating the phases by smearing, burnishing, etc. Black and grey areas represent Au$\mathrm{Cu}$ alloy with a low level of $\mathrm{Ag}$. Black areas are highest in $\mathrm{Cu}$, grey areas are lowest. White areas are $\mathrm{Au}-\mathrm{Ag}$ alloy with a low level of $\mathrm{Cu}$.

grains of artificial $\mathrm{Cu}-\mathrm{free} \mathrm{Ag}-\mathrm{Au}$ alloy that had been mounted and polished with a particle of pure $\mathrm{Cu}$. Because of the softness of $\mathrm{Cu}$, this test will produce the worst-case contamination. This test revealed that away from the $\mathrm{Cu}$-gold alloy junction, no more than $0.2 \mathrm{wt} \%$ $\mathrm{Cu}$ was spread across the test sample. To determine the limits of contamination (from preparation) and fluorescence limits (from particle size or nearest neighbor) for analysis within an inhomogeneous particle, a $0.5-\mathrm{mm}$ wire of pure gold was embedded in a 3-mm wire of pure copper, mounted and polished. A line of analysis points was run across the $\mathrm{Cu}-\mathrm{Au}$ junction. Within the gold, at $>12 \mu \mathrm{m}$ distance from the $\mathrm{Au}-\mathrm{Cu}$ junction (equivalent to a particle $>24 \mu \mathrm{m}$ in diameter), the $\mathrm{Cu}$ values in the gold were between 0.14 and $0.2 \mathrm{wt} \% \mathrm{Cu}$ (i.e., the level of contamination from sample preparation). The value increased to $0.6 \mathrm{wt} \% \mathrm{Cu}$ at $6 \mu \mathrm{m}(12 \mu \mathrm{m}$ in diameter $)$, $1.0 \mathrm{wt} \% \mathrm{Cu}$ at $5 \mu \mathrm{m}(10 \mu \mathrm{m}$ in diameter), $2.0 \mathrm{wt} \% \mathrm{Cu}$ at $3 \mu \mathrm{m}(6 \mu \mathrm{m}$ in diameter). Because $\mathrm{Au}-\mathrm{Cu}$ alloys are harder than pure $\mathrm{Au}$ or $\mathrm{Cu}$, the contamination values are considered maximum values for this study. On the basis of experience analyzing particles of $\mathrm{Au}-\mathrm{Ag}$ alloy in brass mounts, we suggest that for relatively small grains of $\mathrm{Au}-\mathrm{Ag}$ alloy hosted within considerably larger domains of $\mathrm{Cu}-\mathrm{Au}$ alloy, the maximum contamination of the $\mathrm{Au}-\mathrm{Ag}$ alloy by copper probably is less than 0.1 $\mathrm{wt} \% \mathrm{Cu}$, and the total contamination by copper plus fluorescence error is less than $0.5 \mathrm{wt} \% \mathrm{Cu}$ at a distance 
of $10 \mu \mathrm{m}$ from the contact between the two. It is expected that a contamination error of similar magnitude would arise for small grains of $\mathrm{Au}-\mathrm{Cu}$ alloy hosted by larger grains of $\mathrm{Au}-\mathrm{Ag}$ alloy. These results were applied so that exsolution lamellae $<10 \mu \mathrm{m}$ in diameter were not routinely analyzed, and bulk compositions were obtained for fine exsolution-related mixtures by expanding the spot size to $>10 \mu \mathrm{m}$ in diameter (+ in Fig. 6, below). Bulk compositions are not used as representatives of phase compositions. Analytical errors common to bulk compositions (e.g., resulting from data-reduction problems) are unlikely to be sufficiently large to affect the conclusions derived from these analytical results.

\section{REsults}

A review of the data (Table 1, Fig. 5) reveals that the samples from the two geological contexts complement one another, so that the overall interpretation was enhanced by combining the datasets into one. The compositions derived from the 15 Mile sample are lower in Ag content than the particles in the Wheaton sample. For the 15 Mile sample, all but four compositions fall between $\mathrm{AuCu}$ and $\mathrm{Au}_{2} \mathrm{Cu}$. Two of the four fall near 75 at.\% $\mathrm{Au}$, with 7 at.\% Cu. For the Wheaton Creek sample, about a third of the compositions plot toward the $\mathrm{Au}-\mathrm{Ag}$ join, with the remainder falling mostly between $\mathrm{AuCu}$ and $\mathrm{Au}_{2} \mathrm{Cu}$. This difference in $\mathrm{Ag}$ content is reflected in the higher proportion of Wheaton samples that show extensive and complex exsolution-related textures compared to the 15 Mile sample.

The alloy particles were studied in reflected light. Most particles contain gold of more than one composition. Grains of $\mathrm{Au}-\mathrm{Ag}$ alloy are yellow, whereas grains of $\mathrm{Cu}$-rich $\mathrm{Au}-\mathrm{Cu}$ alloy are rich pink. The differing compositions outline a variety of textural relationships among grains making up the particle. These textures are well developed in the sample from the Wheaton Creek placer. The textures can be described in terms of three basic types: massive, blebby and exsolved.

Consideration was given to the possibility that the texture described as "exsolved" might have been caused by crystallographically controlled replacement, but the zoning sequence described below is not consistent with such an origin. The possibility that most of the complex exsolution-induced textures might have been caused by deformation was rejected, as these placer-derived par-

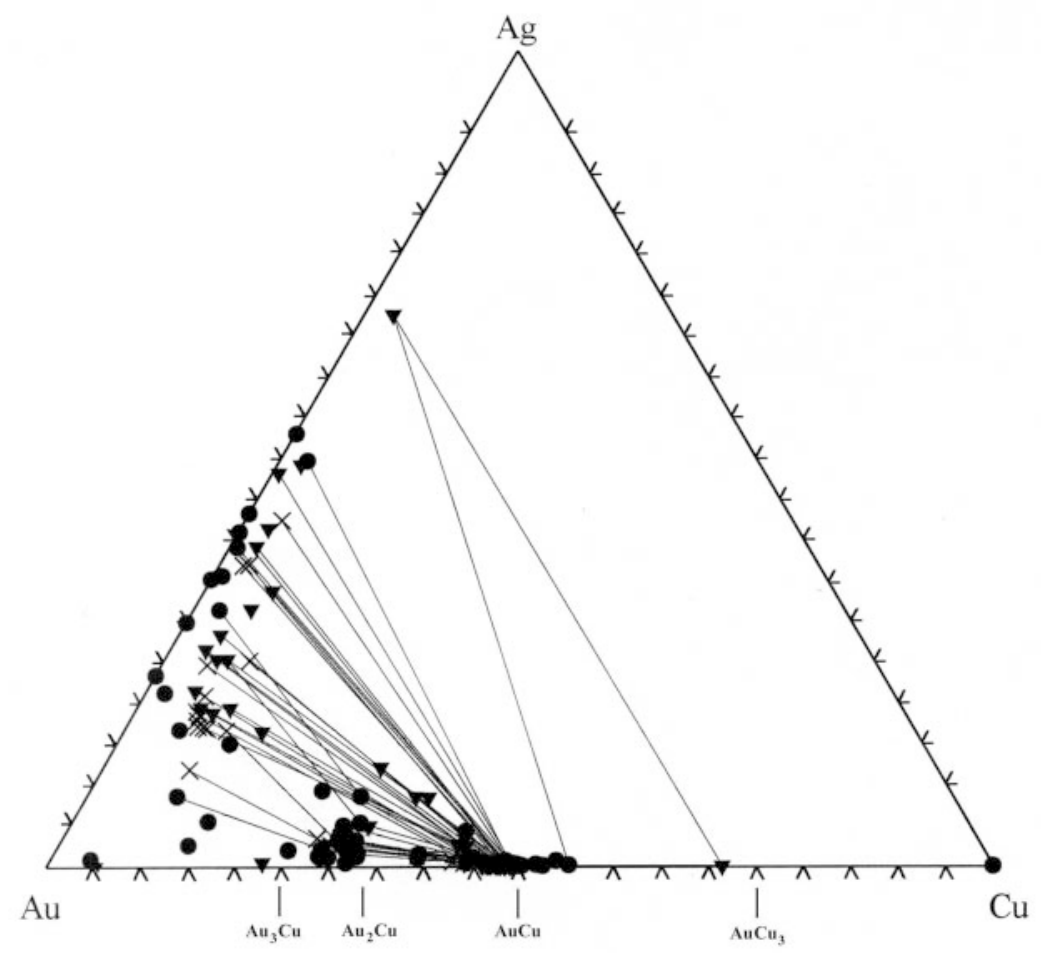

FIG. 5. Data (in at.\%) for the compositions of the principal phases within gold particles from Wheaton Creek and the 15 Mile showing. X: exsolved phase, inverted triangle: blebby phase, $\bullet$ : massive phase. The tie-lines join phases considered to be in equilibrium. 
ticles showed close to the lowest degree of deformation possible, and the formation or preservation of zoning is inconsistent with general deformation. The possibility of localized deformation cannot be rejected, but the similarity of intergrowth textures near the center to those at the edge of particles at all scales suggests that deformation is rare in these samples. For placer particles with this low level of general deformation, the localized deformation is generally concentrated near the edge of the particle (Knight et al. 1999).

Most of the particles have some areas (in a few cases even the whole particle) where no textural features can be recognized. These homogeneous areas are described as massive (e.g., Fig. 3c, grey area at top right of particle). In composite particles, the massive areas usually occur toward the edge of the particle (e.g., Fig. 3d, grey area at the lower left of the particle).

Most particles contain areas of one or both of two types of inhomogeneities, blebby and exsolved. Areas

TABLE 1. REFRESENTATIVE COMPOSITIONS OF GOLD COPPER ALIOY, WHEATOY CREEK, BRITISH COLLMEIA

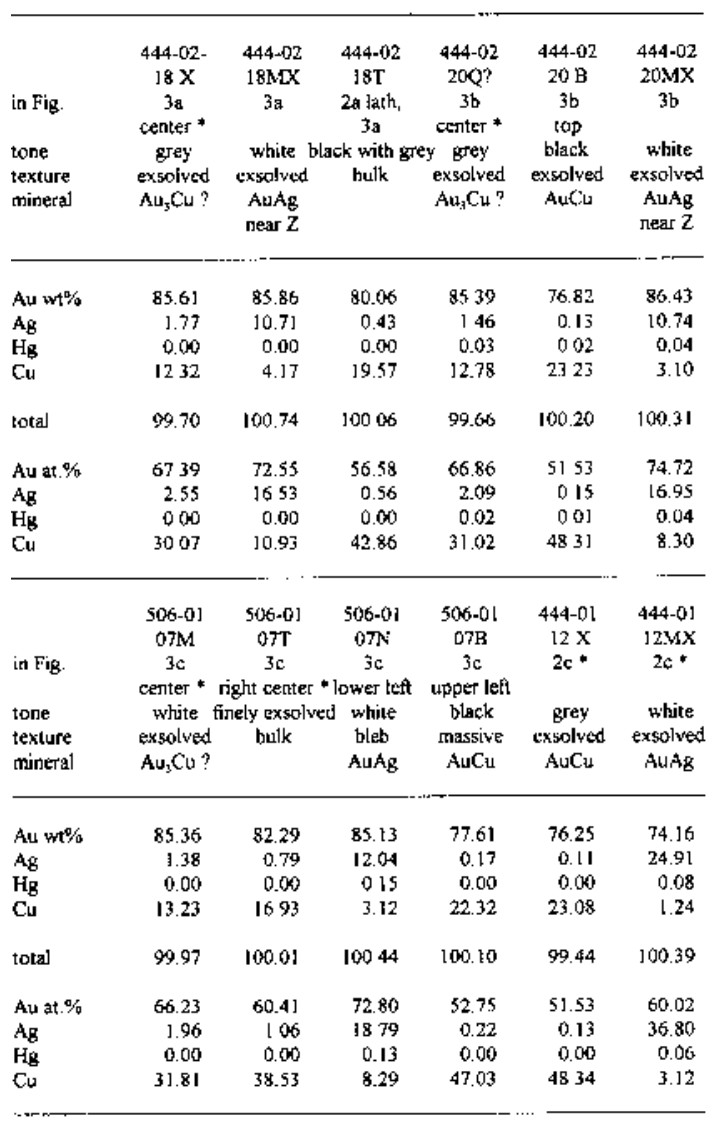

* Analygis point lies within the field of yiew covered by the figure cited. The other compositions are representative of the phases in the figure, but the analyses were made outside the ficld of view Results of electron-miecoprobe analybes. described as blebby are similar to massive areas in that they are internally homogeneous. They differ from massive areas in that they are much smaller. They may be surrounded by massive areas, where they are recognized by their different composition, or may either lie on the boundaries or be surrounded by exsolved areas, where they are recognized by their homogeneity. In the latter case, two blebs of different compositions can occur in the same particle (Fig. 3e, grey and white areas dominating the neck in the particle). In particles dominated by exsolved areas, the blebs usually occur toward the particle edge, whereas in particles with massive and exsolved areas, the blebs are preferentially concentrated toward the boundary between the two areas. In some cases, the blebby areas merge with the massive areas (Fig. 3d, black and grey areas on the left edge of the particle).

Exsolution textures are common. In particles that display exsolved areas, both the contrasting compositions and variable orientations of the exsolution-induced intergrowths outline grain boundaries (Fig. 3b, in particular at the bottom right of the particle; Fig. 4d). Exsolution intergrowths can occupy the whole particle, but in composite particles, they usually occupy only the central portion. Grains showing exsolution-induced intergrowths also serve to outline massive grains and blebs (Fig. 3c, grey area to the left of the particle). Exsolution intergrowths are diverse in their expression (Figs. 3, 4). Thin (occasionally thick) straight, nearly parallel-sided (but ultimately tapered) exsolution lamellae are common, but thicker lens-like and more irregular forms also are found. The latter resemble blebs in some cases. Many exsolution lamellae are composites of multiple events of exsolution. This is most clearly seen in BSE images (Fig. 4a). Different orientations of the lamellae, both in different grains and within exsolution lamellae, create the impression of a network (Figs. 3b, 4c; cf. Murzin \& Sustavov 1989). Examples of the composition of these textural types are reported in Table 1. In Figures 5 and 6, the data are shown along with tie-lines joining phases considered to be in equilibrium.

BSE imaging of the particles confirms the observations in reflected light. However, it also shows that the degree of exsolution is far greater than revealed by light microscopy ( $c f$. Figs. 3a, 4a). Exsolution can occur to the submicrometer scale (Fig. 4). The BSE imaging allows features at the submicrometer scale to be considered during the selection of sites for analysis. Many but not all such sites were checked by BSE imaging, so it is certain that some of the compositions reported represent bulk compositions.

Zoning is crudely developed in composite particles. The exsolved areas lie toward the center, with massive areas on their outer edge. The blebby areas lie near the edge of the exsolved area, either along exsolved grainboundaries or between exsolved and massive areas (Figs. 3d, 4c). In particles that are dominantly massive, 


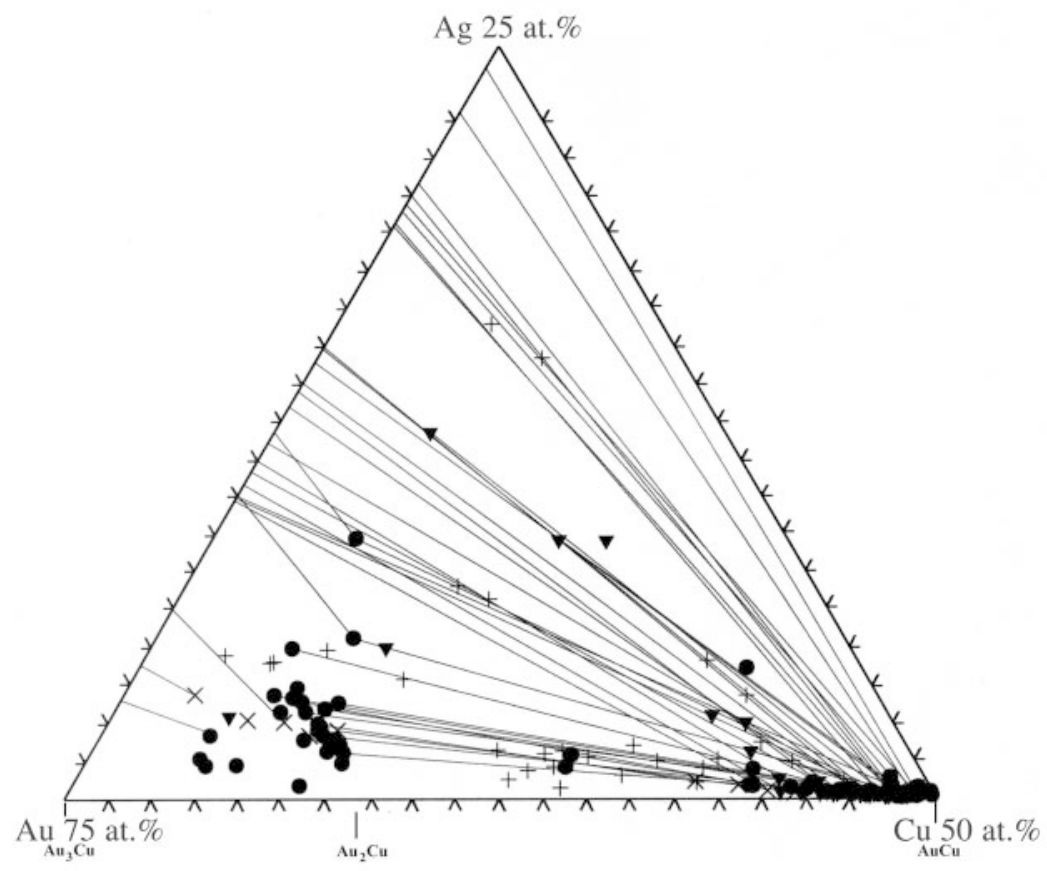

FIG. 6. Details of Figure 5 intended to illustrate the clustering around $\mathrm{AuCu}$ and the composition $\mathrm{Au}_{2} \mathrm{Cu}$, the relationship of $\mathrm{AuCu}$ to $\mathrm{Au}_{2} \mathrm{Cu}$, and the trends used to generate the formulas for $\mathrm{AuCu}$ and $\mathrm{Au}_{2} \mathrm{Cu}$ (see text). For compositions near $\mathrm{AuCu}$, there is overlap of points representing blebby, massive and exsolved material. Symbols as for Figure 5 with the addition of + , representing bulk compositions (in at.\%) of mixed phases.

blebby areas can occur along the edges of the particles. For $\mathrm{Au}-\mathrm{Cu}$ compositions between 50 and 60 at.\% $\mathrm{Au}$, massive phases are generally closest to 50 at.\% Au (mean: $\mathrm{Au}_{1.0} \mathrm{Cu}_{0.97} \mathrm{Ag}_{0.003}$ ), followed by blebby and exsolved phases with increasing Au content. Along the outer margin of some particles, one of two types of zones is found. One is a thin but incomplete zone consisting of a massive phase. Usually, this massive phase can be identified as part of the sequential zoning discussed above and is thus called the edge phase (Fig. 7). A few particles from Wheaton Creek display the second type of zone, which consists of either a thin porous zone or a thin discontinuous gold-rich phase. The characteristics of the porous second type of zone are consistent with the features formed by the leaching of $\mathrm{Ag}, \mathrm{Cu}$ and $\mathrm{Hg}$ from particles of gold alloy in the surficial environment and referred to as rims (Knight et al. 1999). The composition of the massive phases at the edge and the residual gold rims are reported in Figure 7.

Numerous mineral inclusions in gold and attachments to the gold were seen. A detailed study of the inclusions was not undertaken. The following identifications are based on results of qualitative EDS analyses. From the 15 Mile sample, diopside, Fe-poor, $\mathrm{Ca}-$ rich garnet (grossular?), a $\mathrm{Ca}-\mathrm{Al}$ silicate (epidote? vesuvianite?), Ni-Sb alloy, chalcocite, bornite and a $\mathrm{Pt}$, $\mathrm{Pd}, \mathrm{Cd}, \mathrm{S}$ mineral or minerals. The following were identified from the Wheaton Creek area: magnetite, high$\mathrm{Mg}-\mathrm{Fe}$ silicate (pyroxene? olivine?), Mg silicate (serpentine?), calcite, chalcocite, CoNiAs mineral, $\mathrm{CuFeS}$ (bornite?). Large nuggets of copper also are found in the Wheaton placer.

In order to further limit the conditions of formation of the 15 Mile sample, fluid-inclusion studies were undertaken on three samples of rodingite and one of serpentinite from the dump and ore bin. No gold was seen in these samples but, as discussed above, we are certain that the gold is hosted in part by the rodingites. The fluid inclusions measured in this study occur in grossular (three samples; total of 19 inclusions) and diopside (one sample, total of nine inclusions). The fluid inclusions have a restricted single grouping of homogenization temperatures $(T h)$ between 230 and $280^{\circ} \mathrm{C}(28$ determinations). Ice-melting temperatures $(\mathrm{Tm})$ form a single grouping between -0.2 and $-1.4^{\circ} \mathrm{C}(21$ determinations), indicating low salinities in the range 1-2 wt $\%$ eq. $\mathrm{NaCl}$. Eutectic ( $T e$ : first melting) temperatures, mainly in the -30 to $-43^{\circ} \mathrm{C}$ range, rarely to $-54^{\circ} \mathrm{C}$, indicate that $\mathrm{Mg}$ or possibly $\mathrm{Mg}$ and $\mathrm{Ca}$ may be present. The fluid is relatively $\mathrm{CO}_{2}$-poor, as indicated by the 


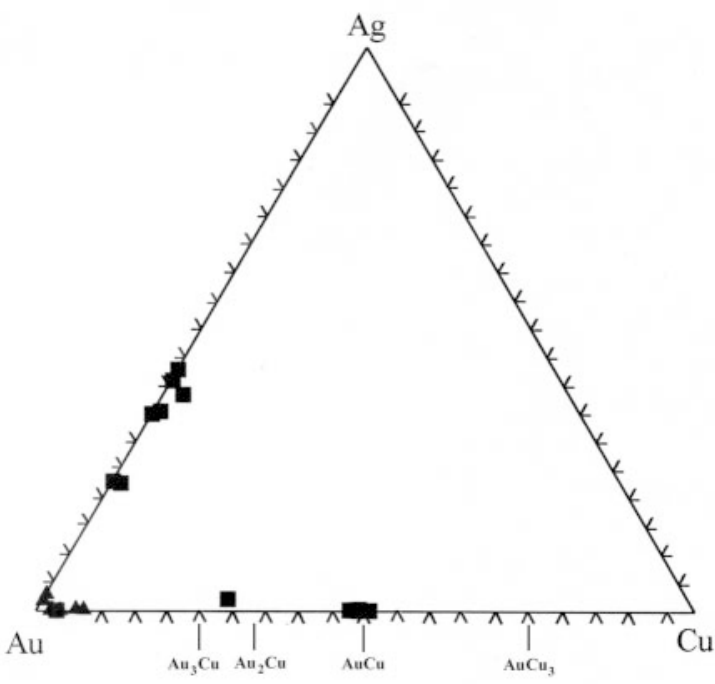

FIG. 7. Composition of the phases (in at.\%) comprising a rim (triangle), apparently generated in the surficial environment, or the edge (square) of the hydrothermal gold particles whose principal phases are plotted in Figure 5. The composition of the edge phase falls in locations expected as a result of low-temperature precipitation. The composition of the rim material is near the range expected by leaching of $\mathrm{Cu}, \mathrm{Ag}$, and $\mathrm{Hg}$ in the surficial environment.

absence of clathrate formation or clathrate-melting events.

\section{INTERPRETATION}

Figures 5 and 6 illustrate the analytical results represented in Table 1, grouped by texture type (blebby, massive, or exsolved phase), with tie lines linking the phases considered to be in equilibrium. The exsolution texture in some particles is simple, and consists of two phases (Fig. 3c), whereas in others, the texture is more complex (Fig. 4a). Upon analysis, these complex textures can be broken down into a series of binary pairs of apparently three end-member compositions. These endmembers, together with the massive and blebby phases, form the clusters and trends seen in Figures 5 and 6 (e.g., around compositions $\mathrm{AuCu}$ and $\mathrm{Au}_{2} \mathrm{Cu}$ ). Bulk compositions of fine intergrowths not amenable to single-phase analysis (Table 1, Fig. 4d) usually fall on the tie-line zones, shown for example in Figures 6. This coincidence suggests that the fine intergrowth results from a latestage or weakly developed exsolution of known phases rather than of some unknown phase.

These results were combined with the results of Pokrovskii et al. (1979) to generate a low-temperature phase diagram for the system $\mathrm{Au}-\mathrm{Ag}-\mathrm{Cu}$ (Fig. 8, near $25^{\circ} \mathrm{C}$ and $1 \mathrm{~atm}$, after sufficient time for equilibration).
This diagram is considered to represent the composition of the phases present with consideration given to the spatial limit of X-ray micro-analysis and to evidence of submicrometer-scale exsolution (where data are available). The most important features of Figure 8 are the recognition of a possible three-phase field involving $\mathrm{AuCu}, \mathrm{Au}_{2} \mathrm{Cu}$ and $\mathrm{Au}_{3} \mathrm{Ag}_{0.71} \mathrm{Cu}_{0.23}$ (referred to as $Z$ for convenience), the observation that the analyzable gold-rich $\mathrm{Au}-\mathrm{Cu}$ alloy in this study has a composition close to that represented by $\mathrm{Au}_{2} \mathrm{Cu}$ rather than the expected stoichiometric composition $\mathrm{Au}_{3} \mathrm{Cu}$ representative of the mineral auricupride, and the presence of a two-phase region on the $\mathrm{Au}$ side of the $\mathrm{Au}_{2} \mathrm{Cu}-Z$ join. The low-Au part of the system (Fig. 8) is in general agreement with the theoretical phase-relationships of Kikuchi et al. (1980), shown in Figure 1. For the medium- and high-Au part of the system, the agreement is very poor, but what is shown likely applies to very different temperatures $\left(240^{\circ}\right.$ and $\left.25^{\circ} \mathrm{C}\right)$. The two tie-lines reported by Bird et al. (1991) are in agreement with Figure 8. For the three-phase region, the bounding compositions on the $\mathrm{Au}-\mathrm{Cu}$ join were determined from the data illustrated in Figure 6. The mean composition for massive phases around $\mathrm{Au}_{1.0} \mathrm{Cu}_{0.97} \mathrm{Ag}_{0.003}$ is considered to represent the maximum deviation from stoichiometry on the Au side of $\mathrm{AuCu}$. This deviation from stoichiometry toward Au is much less extensive than that reported by Okamoto et al. (1987) for experimental systems, and closer to that reported by Murzin \& Sustavov (1989) for natural AuCu. However, for bulk compositions of finely exsolved phases (+ in Fig. 6) near the join $\mathrm{AuCu}-\mathrm{Au}_{2} \mathrm{Cu}$ (and trending toward $\mathrm{AuCu}$ ), the maximum $\mathrm{Au}$ content corresponds to the maximum deviation for $\mathrm{Au}$-enriched $\mathrm{AuCu}$ (II) given by Okamoto et al. (1987). This deviation and the trend toward $\mathrm{AuCu}$ from finely exsolved to blebby to massive phases are considered to represent the effect of a change in temperature with time.

The composition at the triple point, $Z$ (Fig. 8), was chosen to correspond to the point on the edge of the exsolved area which 1) is joined to $\mathrm{AuCu}, 2$ ) is limited by one tie-line to $\mathrm{Au}_{2} \mathrm{Cu}$, the trend in compositions leading away from $\mathrm{Au}_{2} \mathrm{Cu}$, and 3) lies on the curve corresponding to the maximum $\mathrm{Cu}$ in $\mathrm{Au}-\mathrm{Ag}$ alloy compositions, as defined by the boundary between the massive and blebby phases (Fig. 5). Because the exsolution lamellae analyzed are considerably larger than the minimum size of exsolution present (which are nearest equilibrium?), the composition at $Z$ $\left(\mathrm{Au}_{3} \mathrm{Ag}_{0.71} \mathrm{Cu}_{0.23}\right)$ is almost certainly too high in $\mathrm{Cu}$ (Fig. 5). This choice is based on a limited search for exsolution textures. Murzin \& Malyugin (1983) used etching and electron microscopy on natural samples of gold alloy to develop a curve for the boundary between phases showing exsolved and homogeneous phases for the $\mathrm{Au}$ end of the $\mathrm{Au}-\mathrm{Ag}-\mathrm{Cu}$ phase diagram (Fig. 8). Their curve is in agreement with the curve based on our interpretation in that both suggest that $\mathrm{Cu}$ is more 
soluble in $\mathrm{Au}-\mathrm{Ag}$ alloy than is $\mathrm{Ag}$ in $\mathrm{Au}-\mathrm{Cu}$ alloy. The curve of Murzin \& Malyugin (1983) lies nearer to the graph axes and is probably a truer representation of the equilibrium compositions at low temperature (Fig. 8). Their curve suggests that the saturation value of $\mathrm{Cu}$ for $Z$ lies between 1.75 and 2.25 at. $\% \mathrm{Cu}$.

The composition near $\mathrm{Au}_{2} \mathrm{Cu}$ is constrained by the trend in the compositions from $\mathrm{AuCu}$ toward $\mathrm{Au}_{2} \mathrm{Cu}$ and the trend in the compositions of $\mathrm{Au}_{2} \mathrm{Cu}$ toward $Z$ (Fig. 6). The trend toward $Z$ is reinforced by the linear distribution of bulk compositions between $\mathrm{Au}_{2} \mathrm{Cu}$ and $Z$. The following observations are considered to support the conclusion that $\mathrm{Au}_{2} \mathrm{Cu}$ really corresponds to the composition of a phase rather than an analytical error. Natural compositions near $\mathrm{Au}_{2} \mathrm{Cu}$ are reported as stoichiometric $\mathrm{Au}_{3} \mathrm{Cu}$, but are commonly better represented as having a composition near $\mathrm{Au}_{2} \mathrm{Cu}$. For example, Murzin \& Sustavov (1989) reported naturally occurring stoichiometric $\mathrm{AuCu}$ and $\mathrm{AuCu}_{3}$ after a careful selec- tion of samples, but described $\mathrm{Au}_{3} \mathrm{Cu}$ as deviating from stoichiometry. Using their numbers, $12.25 \mathrm{wt} \% \mathrm{Cu}$ (between their reported 12.0 and $12.5 \mathrm{wt} \% \mathrm{Cu}), \mathrm{Ag}$ at 1.5 $\mathrm{wt} \%(<2 \mathrm{wt} \%$ reported), with the balance as gold, the formula for the alloy is $\mathrm{Au}_{2} \mathrm{Cu}_{0.881} \mathrm{Ag}_{0.064}$ (total atoms 2.945), which is equivalent to $\mathrm{Au}_{3} \mathrm{Cu}_{1.322} \mathrm{Ag}_{0.095}$ (total atoms 4.417). The total number of atoms shows that this composition in closer to $\mathrm{Au}_{2} \mathrm{Cu}$ than $\mathrm{Au}_{3} \mathrm{Cu}$ in stoichiometry. This composition falls close to the trend line between $\mathrm{Z}$ and $\mathrm{Au}_{2} \mathrm{Cu}$, near the composition $\mathrm{Au}_{2} \mathrm{Cu}$ (Fig. 6). A further example comes from Knipe \& Fleet (1997). Their reported range in composition for $\mathrm{Au}_{3} \mathrm{Cu}$ (their Fig. 1) covers $\mathrm{Au}_{2} \mathrm{Cu}$ at the high-copper end. Finally, the presence of exsolved areas, blebby areas and tie-lines on the high- $\mathrm{Au}$ side of the join $\mathrm{Au}_{2} \mathrm{Cu}-\mathrm{Z}$ join (Figs. 5, 6) further supports the conclusion that $\mathrm{Au}_{2} \mathrm{Cu}$ is the composition of a phase. It is possible that this composition is caused by the presence of unrecognized or unexposed exsolution-related intergrowths. Such

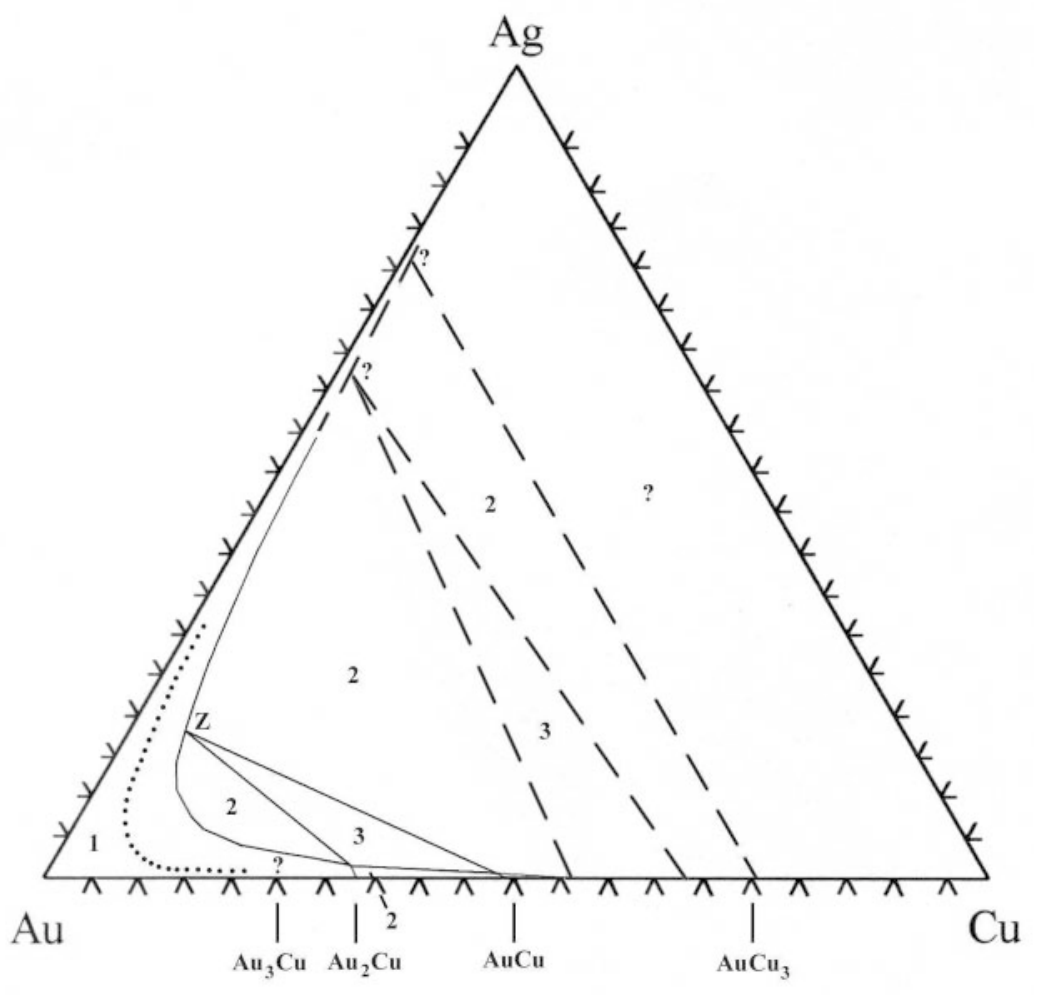

FIG. 8. The proposed phase-diagram for the system $\mathrm{Au}-\mathrm{Cu}-\mathrm{Ag}$ at less than $100^{\circ} \mathrm{C}$ based on data from this study (solid lines) and Pokrovskii et al. (1979) (dashed lines) from the Zolotaya Gora deposit in the Urals. Data from Murzin \& Malyugin (1983) (dotted line) from the Urals region illustrate the lowest $\mathrm{Cu}$ content of gold still showing exsolution reported to date. Areas marked 3 are three-phase, and those marked 1 are one-phase regions, whereas ? indicates points of uncertainty in detail. The composition at $Z$ is $\mathrm{Au}_{3} \mathrm{Ag}_{0.71} \mathrm{Cu}_{0.23}$. The composition limit established in this study for one side around $\mathrm{Au}_{2} \mathrm{Cu}$ is $\mathrm{Au}_{2} \mathrm{Cu}_{0.962} \mathrm{Ag}_{0.045}$, and at $\mathrm{AuCu}$, it is $\mathrm{Au}_{1.0} \mathrm{Cu}_{0.971} \mathrm{Ag}_{0.003}$. 
unrecognized or unexposed intergrowths are considered, in part, to account for the trend from $\mathrm{AuCu}$ toward $\mathrm{Au}_{2} \mathrm{Cu}$ and between $\mathrm{Au}_{2} \mathrm{Cu}$ and $Z$. No such trend in the data is seen between $\mathrm{Au}_{2} \mathrm{Cu}$ and $\mathrm{Au}_{3} \mathrm{Cu}$ (Figs. 5, 8). $\mathrm{Au}_{2} \mathrm{Cu}$ seems to represent the stoichiometry of a valid phase. It thus seems, for the data presented in this study, that the pertinent debate is whether the $\mathrm{Au}_{2} \mathrm{Cu}$ composition reported here is part of the extended but unsampled compositional range of auricupride $\left(\mathrm{Au}_{3} \mathrm{Cu}\right)$ (which may become restricted to stoichiometric $\mathrm{Au}_{3} \mathrm{Cu}$ with a decrease in temperature), or whether $\mathrm{Au}_{3} \mathrm{Cu}$ decomposes into a two-phase region between $\mathrm{Au}$ and $\mathrm{Au}_{2} \mathrm{Cu}$. If stoichiometric $\mathrm{Au}_{3} \mathrm{Cu}$ is indeed the low-temperature phase, then it would be expected that for the appropriate bulk-composition, a trend and clustering of compositions similar to that around $\mathrm{Au}_{2} \mathrm{Cu}$ would be apparent on the excess- $\mathrm{Au}$ side of $\mathrm{Au}_{3} \mathrm{Cu}$.

Synthetic alloys do not provide an answer because the range in composition of each phase is very large for the temperatures studied (e.g., 38.5 to 63 at.\% $\mathrm{Cu}$ for $\mathrm{AuCu}, 10$ to 38.5 at. $\% \mathrm{Cu}$ for $\mathrm{Au}_{3} \mathrm{Cu}$ : Okamoto et al. 1987). The details of the phase diagram around $\mathrm{Au}_{3} \mathrm{Cu}$ are imperfectly known (Okamoto et al. 1987), and in- clude the possibility of a two-phase region around $\mathrm{Au}_{3} \mathrm{Cu}$. Considering that the properties of $\mathrm{Au}_{3} \mathrm{Cu}$ were determined from data at the limit of the experimental method, it would be expected that $\mathrm{Au}_{3} \mathrm{Cu}$ would have the largest range in composition. Perhaps a range in bulk composition closer to Au than that studied here would define the phases around $\mathrm{Au}_{3} \mathrm{Cu}$. A review of published data for natural compositions of $\mathrm{Au}-\mathrm{Cu}$ alloy in this region shows that they do fall between $\mathrm{Au}_{2} \mathrm{Cu}$ and $\mathrm{Au}_{3} \mathrm{Cu}$, but they are too few in number, and it was not possible to evaluate whether the compositions represent single or multiple phases (Fig. 2). Our findings and those of Murzin \& Sustavov (1989) both show at least a twophase region on the $\mathrm{Au}-\mathrm{Ag}$ side of $\mathrm{Au}_{2} \mathrm{Cu}-\mathrm{Au}_{3} \mathrm{Cu}$, but from the very limited data in their study, the $\mathrm{Au}-\mathrm{Ag}$ phase may be joined to $\mathrm{Au}_{2} \mathrm{Cu}$, not $\mathrm{Au}_{3} \mathrm{Cu}$.

In an attempt to clarify this problem, 258 analyses of $\mathrm{Au}-\mathrm{Ag}$ alloy particles from placers in southern British Columbia in which high $(>0.6$ at.\%) $\mathrm{Cu}$ values were reported were plotted (Fig. 9). These particles were checked by optical microscopy and occasionally checked by BSE imaging for exsolution textures before analysis. Although none were recognized, the work of

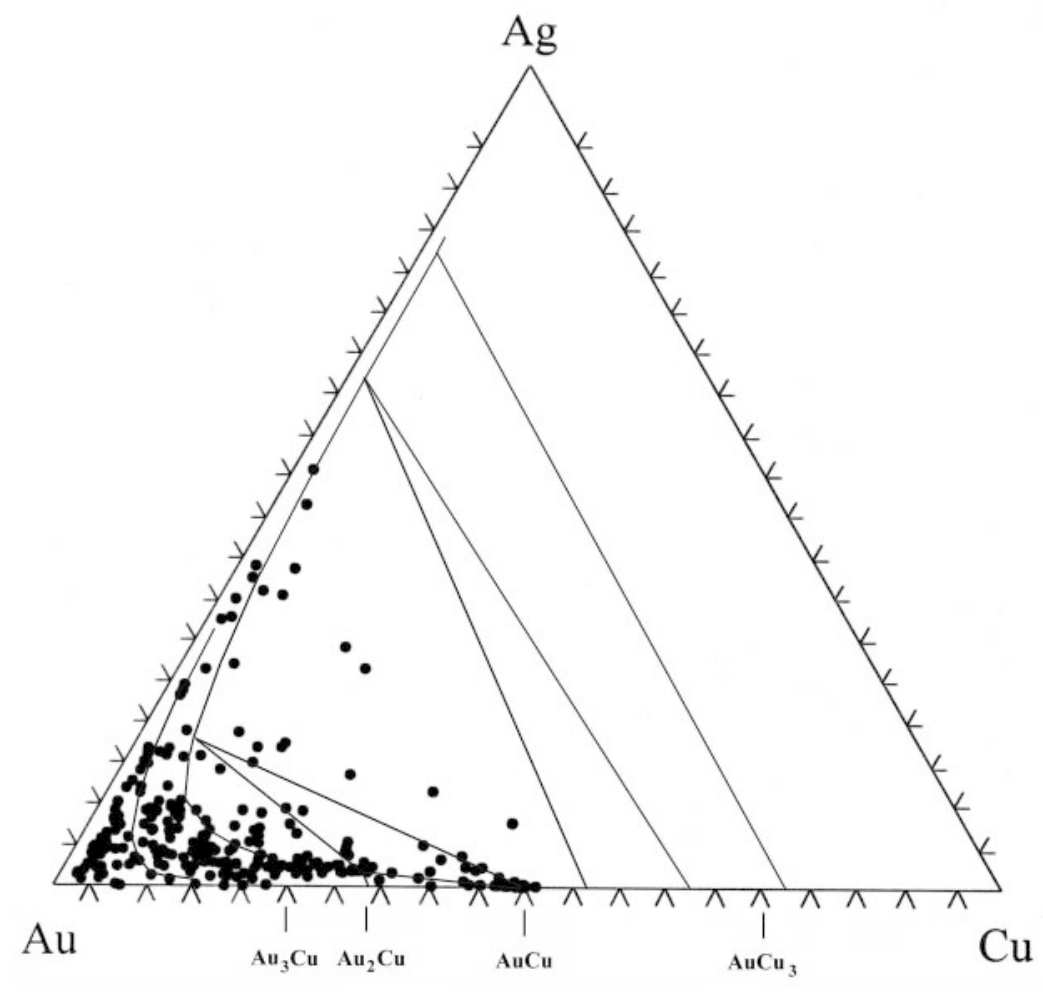

FIG. 9. The analysis of $258 \mathrm{Cu}$-rich phases from placer gold particles. Most particles are from southern British Columbia in the Coquihalla District. Exsolution was checked using reflected light but, as the scatter in the center of the diagram shows, was not always recognized. For convenience, the phase boundaries from Figure 8 also are displayed. 
Murzin \& Malyugin (1983) and our findings suggest that more care is required to identify exsolution textures in compositions plotting toward the Au apex. There is no suggestion of a clustering around $\mathrm{Au}_{3} \mathrm{Cu}$ in Figure 9, nor of a gap in the data between $\mathrm{Au}$ and $\mathrm{Au}_{2} \mathrm{Cu}$. If anything, the data suggest a continuum between $\mathrm{Au}$ and $\mathrm{Au}_{2} \mathrm{Cu}$. The step in the data away from the $\mathrm{Au}-\mathrm{Cu}$ axis around 80 at. $\% \mathrm{Au}$ is noted, but its significance is unclear.

The work of Knipe \& Fleet (1997, Fig. 2) provides further data. The $\mathrm{Au}-\mathrm{Cu}$ alloy compositions they studied are considered to have formed at $130^{\circ} \mathrm{C}$, where the departure from stoichiometry with respect to $\mathrm{Au}_{3} \mathrm{Cu}$ should be less than the variation observed in this study, in which the gold is considered to have initially formed between $230^{\circ}$ and $280^{\circ} \mathrm{C}$. They reported a gap between $\mathrm{Au}$ and $\mathrm{Au}_{3} \mathrm{Cu}$. They also reported a compositional asymmetry with respect to $\mathrm{Au}_{3} \mathrm{Cu}$, with the $\mathrm{Au}$-rich side corresponding to stoichiometric $\mathrm{Au}_{3} \mathrm{Cu}$ and the $\mathrm{Cu}$-rich side falling near $\mathrm{Au}_{2} \mathrm{Cu}$. The quality of the polish and size of phases shown in their Figure 2 suggest that some of these contradictions may be the result of analytical problems.

The small massive grains at the extreme edge of some of the particles are attributed to the composition of the last phases to form at the lowest temperature (Fig. 7, edge). The edge compositions around $\mathrm{AuCu}$ are very close to being stoichiometric, as would be expected. The edge compositions on the $\mathrm{Au}-\mathrm{Ag}$ join have lower $\mathrm{Cu}$ values than those expected from Figure 8, and fall within the line taken from Murzin \& Malyugin (1983). The remaining compositions are suggestive, but too few in number to be definitive. The only edge composition near $\mathrm{Au}_{3} \mathrm{Cu}$ falls between $\mathrm{Au}_{3} \mathrm{Cu}$ and $\mathrm{Au}_{2} \mathrm{Cu}$, and is suggestive of a change from $\mathrm{Au}_{2} \mathrm{Cu}$. A few edge compositions fall near the $\mathrm{Au}$ apex on the $\mathrm{Au}-\mathrm{Cu}$ join. Some of the compositions marked as rim phases fall near these points. The higher-than-expected $\mathrm{Cu}$ values (around 5 at.\% $\mathrm{Cu}$ ) for a rim phase suggest that these phases may be misidentified and are possibly edge phases (the possibility of contamination excepted). Along the $\mathrm{Au}-\mathrm{Cu}$ axis, the curve of Murzin \& Malyugin (1983) lies very close to the $\mathrm{Au}-\mathrm{Cu}$ axis and covers the area around the $\mathrm{Au}$ apex. Unfortunately, there are only two points on their curve beyond 12 at. $\% \mathrm{Cu}$. Both of these compositions lie away from the $\mathrm{Au}-\mathrm{Cu}$ axis and refer to two-phase mixtures. Their composition around 12 at. \% $\mathrm{Cu}$ also represents the highest $\mathrm{Cu}$ content for a single-phase particle. What evidence exists is thus suggestive of a two-phase field on the $\mathrm{Au}$ side of $\mathrm{Au}_{3} \mathrm{Cu}$, but the evidence is far from conclusive.

In this study, mercury reaches 1.2 at.\%, with most values falling below $0.4 \% \mathrm{Hg}$. This is not sufficient to change the geometry of the $\mathrm{Au}-\mathrm{Ag}-\mathrm{Cu}$ phase diagram. Mercury is close to or below detection limits for alloy compositions with $>15$ at. $\% \mathrm{Cu}$ (Ag less than about 5 at.\%). The $\mathrm{Hg}$ values are highest in low- $\mathrm{Cu} \mathrm{Au}-\mathrm{Ag}$ alloy, which is in agreement with the findings of
Pokrovskii et al. (1977), who reported $\mathrm{Hg}$ values up to $10 \mathrm{wt} \%$. There is a weak correlation between increases in $\mathrm{Ag}$ and in $\mathrm{Hg}$. A similar but strong correlation was reported by Pokrovskii et al. (1977).

\section{DisCUSSION}

Knipe \& Fleet (1997) have suggested that the presence of various $\mathrm{Au}-\mathrm{Cu}$ alloy compositions represents a change in the bulk composition of the system with time, but this is not considered to be necessarily the case. For this study, at least the textures and zoning shown by both reflected-light images (Fig. 3) and the BSE images (Fig. 4) can be understood with reference to the proposed phase-diagram (Fig. 8). These features are attributed to a combination of exsolution and precipitation as the composition of the phases changed with time within the one-, two- and three-phase fields. Because the solvi move rapidly with temperature in the $\mathrm{Au}-\mathrm{Cu}-\mathrm{Ag}$ phase diagram (Kikuchi et al. 1980), we expect that a change in temperature rather than in composition is responsible for variations with time. On the basis of Figure $3 \mathrm{e}$ as an example and under the assumption that the bulk composition of the fluid remained constant, the first gold to precipitate plots in a one-phase field. As the temperature dropped, the gold passed into a two-phase field, at which time the blebby areas were precipitated, and the single phase started to exsolve. With a further drop in temperature, the compositions diverged further, one to be precipitated as the thin massive outer phase on the particle, and the other at a different site. At the same time, exsolution within the blebby area at the micrometer to submicrometer level may have started, and the composition of exsolution lamellae making up the original single phase will have diverged. A more complex example of the exsolution sequence can be seen in Figures $3 \mathrm{a}$ and $4 \mathrm{a}$, where three distinct phases are exsolved. In zoned particles, the appearance of the blebby phases may represent the temperature at the beginning of precipitation in a two-phase field. With this model, the data of Knipe \& Fleet (1997) can be interpreted to represent precipitation from (or reaction with) a low-temperature fluid that varied in composition with location, but was essentially constant with time. For example, their phase 2 could have formed with their phase 3 in a two-phase field. This is not to say that changes in fluid composition did not take place, only that the changes were smaller than those seen by the phase separation. This model also suggests that the Wheaton sample comes from a lode formed at a higher temperature than at the 15 Mile showing.

The curve of Murzin \& Malyugin (1983) is taken to represent the maximum $\mathrm{Cu}$ soluble in $\mathrm{Au}-\mathrm{Ag}$ alloy before exsolution takes place (Figs. 6, 10). The amount of $\mathrm{Cu}$ in $\mathrm{Au}-\mathrm{Ag}$ alloy from areas where a $\mathrm{Cu}-\mathrm{Au}$ alloy is not present is given by the other curves in Figure 10. The figures and data from which these curves were taken show two types of "maxima": a maximum line below 


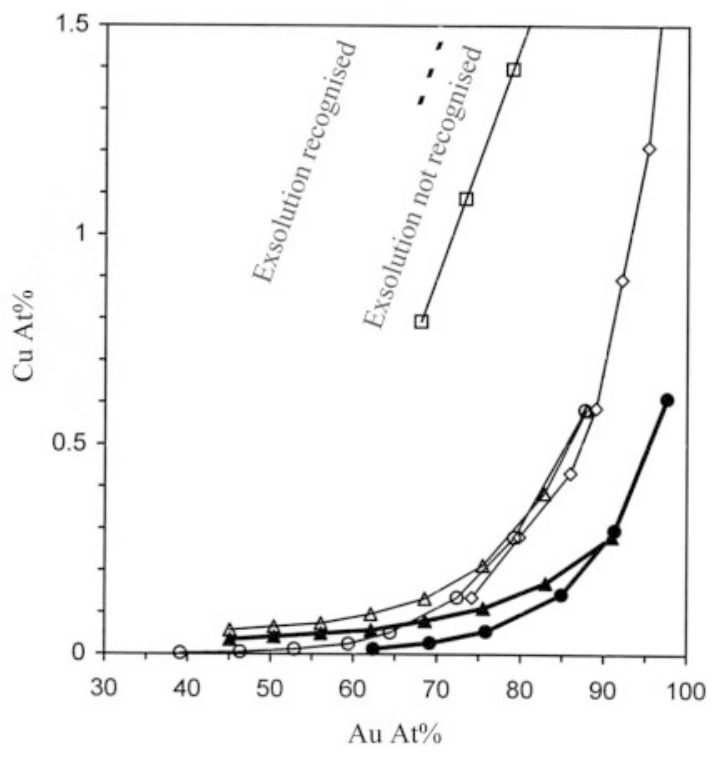

FIG. 10. Limits to the $\mathrm{Cu}$ content in the most common $\mathrm{Au}-$ Ag alloy compositions. The dashed line is from Murzin \& Malyugin (1983), established for material from the Urals region. It separates compositions for which exsolution has been observed (below dashed line) from those where it has not. There are few data-points between the dashed "exsolution" line and the "upper limit" line (open squares) for the Urals region (226 analytical data from Murzin \& Malyugin 1983). The upper limit curve for the YanoKolyma region is shown by open diamond symbols (from Murzin \& Malyugin 1983) and open circles (approximately 220 analytical data from Samusikov \& Petrova 1983). The upper limit curve for the Yukon and British Columbia is shown by the black triangles (>3500 analytical data from Knight \& McTaggart 1990, McTaggart \& Knight 1993, Knight et al. 1999). Open symbols and thin lines are upper limits, solid symbols and thick lines are maximum values; see text.

which most but not all points fall, and the upper limit, a line above which no points fall. The upper-limit line is taken to represent the absolute maximum amount of $\mathrm{Cu}$ found in grains of $\mathrm{Au}-\mathrm{Ag}$ alloy for that region. The upper-limit line for the Urals shows that grains of $\mathrm{Au}-$ $\mathrm{Ag}$ alloy from this region do indeed have higher-thannormal $\mathrm{Cu}$. The upper-limit lines for the Yano-Kolyma region of Russia and for British Columbia - Yukon are essentially the same. At first glance, these curves suggest that these lines, rather than the curve of Murzin \& Malyugin (1983), represent the maximum $\mathrm{Cu}$ content possible in an Au-Ag alloy. However, deposits that host $\mathrm{Au}-\mathrm{Ag}$ alloy but no $\mathrm{Au}-\mathrm{Cu}$ alloy are formed over the same range in temperature as the deposits hosting a $\mathrm{Au}-$
$\mathrm{Cu}$ alloy. The difference between the two assemblages appears to have more to do with the fluid precipitating the metals than with an error in the phase diagram. Invariably, grains of $\mathrm{Au}-\mathrm{Cu}$ alloy are associated with native metals, sulfides are not common, and a substantial proportion of them are low-sulfur varieties such as bornite and chalcocite (e.g., Pokrovskii et al. 1979, this study). In gold deposits without grains of $\mathrm{Au}-\mathrm{Cu}$ alloy, the $\mathrm{Au}-\mathrm{Ag}$ alloy is invariably associated with significant amounts of the common sulfides such as pyrite and arsenopyrite (Boyle 1979). We suggest that the amount of $\mathrm{Cu}$ in $\mathrm{Au}-\mathrm{Ag}$ alloy from deposits with no $\mathrm{Au}-\mathrm{Cu}$ alloy is controlled by the presence of additional elements, in particular sulfur, in the system. The Yano Kolyma and British Columbia - Yukon curves may represent the undersaturation of $\mathrm{Cu}$ in $\mathrm{Au}-\mathrm{Ag}$ alloy caused by this difference, and thus contain information about the process of formation of a deposit, not the $\mathrm{Cu}$ limit in $\mathrm{Au}-\mathrm{Ag}$ alloy compositions.

\section{Conclusions}

The composition and textures of natural alloy that result from long periods of equilibration at low temperatures (near $25^{\circ} \mathrm{C}$ ?) can be used to construct a phase diagram for the system $\mathrm{Au}-\mathrm{Cu}-\mathrm{Ag}$. The most important features of the diagram proposed from the results of this study are the recognition of a three-phase field between $\mathrm{AuCu}\left(\mathrm{Au}_{1.0} \mathrm{Cu}_{0.971} \mathrm{Ag}_{0.003}\right), \mathrm{Au}_{2} \mathrm{Cu}\left(\mathrm{Au}_{2} \mathrm{Cu}_{0.962} \mathrm{Ag}_{0.045}\right)$, and $\mathrm{Au}_{3} \mathrm{Ag}_{0.71} \mathrm{Cu}_{0.23}$, the presence of a two-phase region for alloy compositions on the Au side of this three-phase field, and the observation that the compositional range around $\mathrm{Au}_{2} \mathrm{Cu}$ is restricted. $\mathrm{AuCu}$ is nearly stoichiometric. Even after taking into account the problem of micrometer-scale exsolution, the evidence suggests that the compositions around $\mathrm{Au}_{2} \mathrm{Cu}$ are representative, within the limits of this study. The details of the phase diagram between compositions $\mathrm{Au}, \mathrm{Au}_{3} \mathrm{Cu}$ and $\mathrm{Au}_{2} \mathrm{Cu}$ are unclear. Whether there is solid solution over the range $\mathrm{Au}$, $\mathrm{Au}_{3} \mathrm{Cu}$ and $\mathrm{Au}_{2} \mathrm{Cu}$, or whether there are miscibility gaps, remains unresolved. The study of exsolution intergrowths by Murzin \& Malyugin (1983) sets a limit for the amount of $\mathrm{Ag}$ in $\mathrm{Au}-\mathrm{Cu}$ alloy and the amount of $\mathrm{Cu}$ in $\mathrm{Au}-\mathrm{Ag}$ alloy beyond which exsolution occurs. The values for $\mathrm{Cu}$ in $\mathrm{Au}-\mathrm{Ag}$ alloy are low, but not as low as those reported for $\mathrm{Au}-\mathrm{Ag}$ alloy from deposits where $\mathrm{Au}-\mathrm{Cu}$ alloy is absent. These very low values are considered to reflect the chemical composition of the fluid associated with deposition, and do not reflect the phase diagram. The extensive exsolution-induced textures and their relation to the blebby and massive textures are explained by combining the phase diagram with the significant shift in the solvi position with temperature in this system. For example, blebby textures are considered to occur as precipitation changes from a one- to a two-phase field. Mercury is preferentially partitioned into low-Cu, high- $\mathrm{Ag}$ gold alloy. 


\section{ACKNOWLEDGEMENTS}

Dr. K.C. McTaggart is acknowledged for recognizing the significance of $\mathrm{Cu}$-rich gold and for encouraging this study. We thank J. Schussler for the Wheaton sample, and Sun Min and K. Wilkie for help in collecting the 15 Mile sample. The reflected-light photographs were taken by E. Montgomery. Y. Douma and B. Cranston provided high-quality technical assistance. J. McIntosh graciously helped with finding and translating some of the Russian literature. I. Zergsky translated the remainder of the Russian literature. Funding for the analyses was provided by the British Columbia Ministry of Energy, Miners and Petroleum Resources and Westmin Resources Limited. Thanks to S. Knipe and E. Essene, whose reviews greatly improved this manuscript.

\section{REFERENCES}

BARRETT, C.S. \& MASSALSKI, T.B. (1980): Structure of Metals $\left(3^{\text {rd }}\right.$ ed.). Pergamon Press, New York, N.Y.

Bird, D.K., BRooks, C.K., GANNICOTT, R.A. \& TURner, P.A. (1991): A gold-bearing horizon in the Skaergaard intrusion, east Greenland. Econ. Geol. 86, 1083-1092.

BowLES, J.F.W. (1984): The distinctive low-silver gold of Indonesia and East Malaysia. In Gold 82: The Geology, Geochemistry and Genesis of Gold Deposits (R.P. Foster, ed.). Geol. Soc. Zimbabwe, Spec. Publ. 1, 249-260.

BoyLE, R.W. (1979): The geochemistry of gold and its deposits. Geol. Surv. Can., Bull. 280.

CAIRnEs, C.E. (1930): The Serpentine Belt of Coquihalla Region, Yale District, British Columbia. Geol. Surv. Can., Sum. Rep., 1929, 144A-195A.

Douma, Y.L. \& KNIGHT, J.B. (1994): Mounting samples in methyl methacrylate for SEM and EMP studies. J. Sed. Res. A64, 675-677.

Dowdell, R.L., JerabeK, H.S., Forsyth, A.C. \& Green, C.H (1943): General Metallography. John Wiley \& Sons, New York, N.Y.

Holland, S. (1940): Placer gold deposits: Wheaton (Boulder) Creek, Cassiar district, northern British Columbia. B.C. Dep. Mines, Bull. 2, 1-44.

Kikuchi, R., Sanchez, J.M., De Fontaine, D. \& Yamauchi, H. (1980): Theoretical calculation of the $\mathrm{Cu}-\mathrm{Ag}-\mathrm{Au}$ coherent phase diagram. Acta Metall. 28, 651-662.

KNIGHT, J. \& McTAGgaRT, K.C. (1989): Composition of gold from southwestern British Columbia, a progress report. B.C. Dep. Energy, Mines, Petroleum Resources, Geol. Fieldwork 1988, Pap. 1989-1, 387-394.
$\&$

(1990): Lode and placer gold of the Coquihalla and Wells areas, British Columbia $(92 \mathrm{H}, 93 \mathrm{H})$. B.C. Energy, Mines, Petroleum Resources, Exploration in British Columbia 1989, 105-118.

Morison, S.R. \& MoRTEnsen, J.K. (1999): The relationship between placer gold particle shape, rimming, and distance of transport as exemplified by gold from the Klondike district, Yukon Territory, Canada. Econ. Geol. 94, 635-648.

KNIPE, S.W. \& FLEET, M.E. (1997): Gold-copper alloy minerals from the Kerr mine, Ontario. Can. Mineral. 35, 573-586.

Kogachi, M \& NAKAHIGASHI, K. (1980): Phase relations in the $\mathrm{Cu}_{3} \mathrm{Ag}_{1-x} \mathrm{Au}_{x}, \mathrm{Ag}_{3} \mathrm{Au}_{1-x} \mathrm{Cu}_{x}, \mathrm{Au}_{3} \mathrm{Cu}_{1-x} \mathrm{Ag}_{x}$ ternary system. Japan. J. Appl. Phys. 19, 1443-1449.

Kuznetsov, Yu.A., Panov, B.S., SAmoilovich, L.G. Sharkin, O.P. \& LaZarenko, E.K. (1977): Cuprous gold in the Donetsk Basin. Vopr. Reg. Genet. Mineral., S'ezde Ukr. Mineral. Obshchest. (E.K. Lazerenko, ed.). Naukova Dumka, Kiev, USSR (59-63; in Russ.). (Chem. Abstr. 88: $173534 x$ ).

MAO, S.H. \& LiU, T.X. (1984): A study of gold-copper minerals using the electron probe. J. Phys., Colloq. C2, suppl. 45, 631-634.

McTaggart, K.C. \& KNight, J.B. (1993): Geochemistry of lode and placer gold of the Cariboo district, B.C. B.C. Dep. Energy, Mines, Petroleum Resources, Open File 1993-30, 1-26.

Monger, J.W.H., Price, R.A. \& Templeman-Kluit, D.J. (1982): Tectonic accretion and the origin of the two major metamorphic and plutonic welts in the Canadian Cordillera. Geology 10, 70-75.

Murzin, V.V., Kudryavtsev, V.I., Berzon, R.O. \& Sustavov, S.G. (1987): Cupriferous gold in rodingitized zones. Geol. Rudn. Mestorozhd. 29(5), 96-99 (in Russ.).

\& Malyugin, A.A. (1983): New data on the instability of natural solid solutions of the gold-silver-copper system at temperatures below $350^{\circ} \mathrm{C}$. Dokl. Acad. Sci. USSR, Earth Sci. Sect. 269, 723-724.

\& Moloshag, V.P. (1986): Typomorphism of gold of pyrite deposits of the Urals. In Geochemistry and Mineralogy of Primary and Secondary Haloes (N.A. Grigor'yev, V.V. Murzin \& V.N. Savonov, eds.). Akad. Nauk SSSR - Uralskii Nauchmit Tsentr. Sverdlovsk, 100107 (in Russ.). (Chem. Abstr. 107:26229j).

\& Sustavov, S.G. (1989): Solid-phase transformation in native cupriferous gold. Izv. Akad. Nauk SSSR, Ser. Geol. 11, 94-104 (in Russ.). (Chem. Abstr. 114(2):9751a).

Novgorodova, M.I. \& TsePIn, A.I. (1976): Phase compositions of cupriferous gold. Dokl. Acad. Sci. USSR, Earth Sci. Sect. 227, 121-123. 
Okamoto, H., Chakrabarti, D.J., Laughlin, D.E. \& MASSALSKI, T.B. (1987): The Au-Cu (gold - copper) system. Bull. Alloy Phase Diagram 85, 454-474.

Petrovskaya, N.V. \& Novgorodova, M.I. (1980): Heterogeneity of native gold and some problems relating to stability of natural solid solutions of metals. In Inhomogeneity of Minerals and Crystal Growth. Proc. XI Gen. Meeting (Moscow, 1978), Int. Mineral. Assoc., 76-86, 296-297, 330 (in Russ.).

, Frolova, K.E. \& TSEPIN, A.I. (1977): Nature of the nonuniformity and phase composition of endogenic segregations of native gold. Neodnordnost Miner. Tonkie Miner. Smesi, (F.V. Chukhrova \& N.V. Petrovskaya, eds.). Nauka, Moscow, Russia (16-27; in Russ.). (Chem. Abstr. 89:046532r).

PokrovskiI, P.V. \& Berzon, R.O. (1975): Composition of copper and silver gold from the deposit Zolotaya Gora. Ezheg., Inst. Geol. Geokhim., Akad. Nauk SSSR, Ural. Nauchn. Tsentr. 1974, 94-97 (in Russ.). (Chem. Abstr. 86:7236r).

Murzin, V.V., Berzon, R.O. \& Yunikova, B.A. (1979): Mineralogy of native gold from the Zolotaya Gora deposit. Zap. Vses. Mineral. Obshchest. 108, 317-326 (in Russ.). (Chem. Abstr. 91:143452p).

, Sandler, G.A., Chesnokov, B.V., Berzon, R.O., Aleksandrov, A.I., Barannikov, A.G. \& Khrypova, R.G. (1977): Characteristics of distribution of silver, iron, copper and bismuth in native gold of some Ural deposits. Tr. In-ta Geol. Geokhimii Ural'sk, Nauch. Tsentr, Akad. Nauk SSSR 131, 120-124 (in Russ.). (Chem. Abstr. 90:207442z).
RAICEVIC, D. \& CABRI, L.J. (1976): Mineralogy and concentration of Au- and Pt-bearing placers from the Tulameen River area in British Columbia. Can. Inst. Mining Metall. Bull. 69(770), 111-119.

RAY, G.E. (1990): The geology and mineralization of the Coquihalla gold belt and Hozameen fault system, southwestern British Columbia. B.C. Dep. Energy Mines, Petroleum Resources, Bull. 79, 1-97.

Samusikov, V.P. \& Petrova, N.I. (1983): Correlations between the content of silver, antimony and copper in native gold (deposits of the Yana-Kolyma belt as examples). In The Typomorphic Features of Ore Minerals from the Endogenic Formations of Yakutia (B.L. Flerov, ed.). Yakutskii Filial SQ Akad. Nauk SSSR, 39-53 (in Russ.). (Chem. Abstr. 101:114234p).

StumpFl, E.F. \& Clark, A.M. (1965): Electron-probe microanalysis of gold platinoid concentrates from southeast Borneo. Trans. Inst. Mining Metall. B 74, 933-946.

$$
\&
$$

(1966): Electron-probe microanalysis of gold platinoid concentrates from southeast Borneo. Discussion. Trans. Inst. Mining Metall. B 75, 306.

White, J.L., OrR, R.L. \& Hultgren, R. (1957): The thermodynamic properties of silver-gold alloys. Acta Metall. 5, 747-760.

Yamauchi, H., Yoshimatsu, H., Forouhi, H. \& De Fontaine, D. (1981): Phase relations in $\mathrm{Cu}-\mathrm{Ag}-\mathrm{Au}$ ternary alloys. In Precious Metals 1981. Proc. 4th Int. Metall. Conf., 214-249.

Received February 29, 2000, revised manuscript accepted March 31, 2001. 